\title{
Benzo-pyrones for reducing and controlling lymphoedema of the limbs (Review)
}

\author{
Badger CMA, Preston NJ, Seers K, Mortimer PS
}

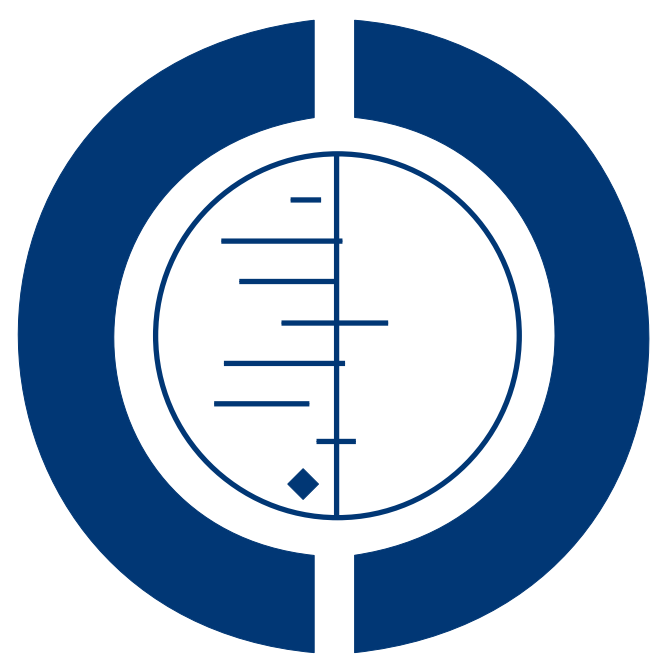

\section{THE COCHRANE COLLABORATION $^{\circledR}$}

This is a reprint of a Cochrane review, prepared and maintained by The Cochrane Collaboration and published in The Cochrane Library 2009, Issue 1

http://www.thecochranelibrary.com

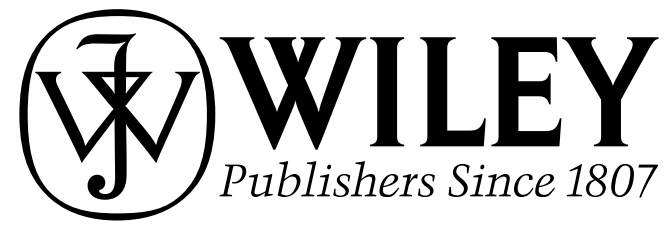

Benzo-pyrones for reducing and controlling lymphoedema of the limbs (Review)

Copyright (@) 2009 The Cochrane Collaboration. Published by John Wiley \& Sons, Ltd. 
TABLE OF CONTENTS

HEADER . . . . . . . . . . . . . . . . . . . . . . . . . . . . . . . . . . . . . . . . . . 1

ABSTRACT . . . . . . . . . . . . . . . . . . . . . . . . . . . . . . . . . . . . . . . . . . . . . . . . . . . 1

PLAIN LANGUAGE SUMMARY $\quad . \quad$. . . . . . . . . . . . . . . . . . . . . . . . . . . . . . . . . . . . . . . .

BACKGROUND . . . . . . . . . . . . . . . . . . . . . . . . . . . . . . . . . . . . . 2

OBJECTIVES . . . . . . . . . . . . . . . . . . . . . . . . . . . . . . . . . . . . . . . . . . 3

METHODS . . . . . . . . . . . . . . . . . . . . . . . . . . . . . . . . . . . . . . 3

RESULTS . . . . . . . . . . . . . . . . . . . . . . . . . . . . . . . . . . . . . . . 5

DISCUSSION . . . . . . . . . . . . . . . . . . . . . . . . . . . . . . . . . . . . . 23

AUTHORS' CONCLUSIONS . . . . . . . . . . . . . . . . . . . . . . . . . . . . . . . . . . . . . . . . . 24

ACKNOWLEDGEMENTS . . . . . . . . . . . . . . . . . . . . . . . . . . . . . . . . . . . . . . . . . . . 24

REFERENCES . . . . . . . . . . . . . . . . . . . . . . . . . . . . . . . . . . . . . 24

CHARACTERISTICS OF STUDIES . . . . . . . . . . . . . . . . . . . . . . . . . . . . . . . . . . . . . . $\quad .26$

DATA AND ANALYSES . . . . . . . . . . . . . . . . . . . . . . . . . . . . . . . . . . . . . . . . . 43

WHAT'S NEW . . . . . . . . . . . . . . . . . . . . . . . . . . . . . . . . . . . . . 43

HISTORY . . . . . . . . . . . . . . . . . . . . . . . . . . . . . . . . . . . . . . . 43

CONTRIBUTIONS OF AUTHORS . . . . . . . . . . . . . . . . . . . . . . . . . . . . . . . . . . . . . 43

DECLARATIONS OF INTEREST . . . . . . . . . . . . . . . . . . . . . . . . . . . . . . . . . . 43

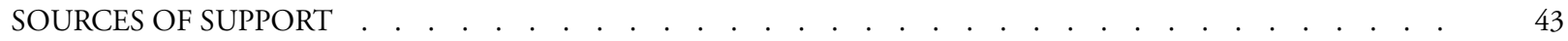

INDEX TERMS . . . . . . . . . . . . . . . . . . . . . . . . . . . . . . . . . . . . 44 


\title{
Benzo-pyrones for reducing and controlling lymphoedema of the limbs
}

\author{
Caroline M A Badger ${ }^{2}$, Nancy J Preston ${ }^{1}$, Kate Seers ${ }^{1}$, Peter S Mortimer ${ }^{3}$ \\ ${ }^{1}$ Research Team, RCN Institute, Oxford, UK. ${ }^{2}$ Institute Research Team, Royal College of Nursing Institute, London, UK. ${ }^{3}$ Division \\ of Physiological Medicine, Cardiac and Vascular Sciences, St Georges Hospital Medical School, London, UK
}

Contact address: Kate Seers, Research Team, RCN Institute, Radcliffe Infirmary, Woodstock Rd, Oxford, OXON, OX2 6HE, UK. kate.seers@rcn.org.uk.

Editorial group: Cochrane Breast Cancer Group.

Publication status and date: Edited (no change to conclusions), published in Issue 1, 2009.

Review content assessed as up-to-date: 25 September 2003.

Citation: Badger CMA, Preston NJ, Seers K, Mortimer PS. Benzo-pyrones for reducing and controlling lymphoedema of the limbs. Cochrane Database of Systematic Reviews 2003, Issue 4. Art. No.: CD003140. DOI: 10.1002/14651858.CD003140.pub2.

Copyright (C) 2009 The Cochrane Collaboration. Published by John Wiley \& Sons, Ltd.

\section{A B S T R A C T}

\section{Background}

Lymphoedema is the accumulation of excess fluid in the body caused by obstruction of the lymphatic drainage mechanisms. Treatment with Benzo-pyrones is thought to reduce fluid forming in the subcutaneous tissues and reduce pain and discomfort of the affected area.

\section{Objectives}

To assess the effectiveness of benzo-pyrones compared to placebo in the management of lymphoedema.

\section{Search strategy}

We searched the Cochrane Breast Cancer Group register (September 2003), the Cochrane Central Register of Controlled Trials (The Cochrane Library, Issue 4,2003), MEDLINE, EMBASE, CINAHL, UnCover, PASCAL, SIGLE, reference lists produced by The British Lymphology Society, the National Research Register (NRR) and The International Society of Lymphology congress proceedings.

\section{Selection criteria}

Randomised controlled trials comparing Benzo-pyrones with placebo.

\section{Data collection and analysis}

Trials were selected for eligibility and tested for quality by two blinded reviewers who independently extracted data. Meta-analysis was not performed due to the poor quality of the trials.

\section{Main results}

Fifteen trials were included. Three oxerutin trials tested the same dose over 6 months against placebo and included a total of 127 participants (data were available for 81). There were insufficient data from these to calculate the per cent reduction or increase in baseline excess limb volume.

One trial testing Cyclo 3 Fort (approved name) was found (57 participants) but insufficient data was provided to allow a proper analysis of its findings. A single trial of Daflon (approved name) was found (104 participants) but this also provided insufficient information to reach a conclusion about the effectiveness of the drug. Three trials of coumarin combined with troxerutin were found which tested 
two different doses of the drug against each other with no placebo, however participant numbers and baseline data were not provided. Eight trials of coumarin were identified. Two of these reported the same trial and the other potentially also referred to the same trial but this could not be confirmed. A further two papers also appeared to refer to the same trial but again this was unconfirmed.

Five studies added anti-filarial drugs to the interventions tested. Participant data could not be extracted and the reporting of outcome measures in most was unclear. Loprinzi's 1999 trial was reported in more detail but its conclusions were very much at odds with other findings.

\section{Authors' conclusions}

It is not possible to draw conclusions about the effectiveness of Benzopyrones in the management of lymphoedema from the current available trials.

\section{PLAIN LANGUAGE SUMMARY}

\section{Benzopyrones for reducing and controlling lymphoedema of the limbs}

Lymphoedema is an accumulation of excess fluid, mainly in the arms and legs. It can occur in several ways: from birth; as a result of a parasitic infection; or as a complication of cancer surgery. The most common treatments are compression hosiery (e.g. bandaging, sleeves, etc.), skin care and exercise. The drugs commonly known as benzo-pyrones have been prescribed to prevent the fluid leakage and collection which characterises lymphoedema. This review found that there was not enough good quality evidence to draw conclusions about whether benzo-pyrones are useful either in reducing lymphoedema or the pain and discomfort associated with it.

\section{B A C K G R O U N D}

Lymphoedema is a chronic and progressive condition resulting from an abnormality of, or damage to the lymphatic system. Any reduction in the capacity of the lymphatic system to drain fluid from the interstitium (a small gap in the tissue) and return it to the blood circulation will cause fluid to build up in the skin and the subcutaneous tissues of the affected part of the body (Mortimer 1995; Levick 1991).

Lymphoedema has many causes but the main ones are:

1.cancer and its treatment - leading to secondary lymphoedema;

2.congenital abnormalities of the lymphatic system - so called primary lymphoedema;

3.chronic venous disease of the lower limb - lympho-venous oedema;

4.filariasis, a parasitic infection - leading to secondary lymphoedema.

The incidence of lymphoedema following breast cancer treatment is difficult to assess due to differences in assessments made of diagnosis, measurement and follow-up time. Petrek 1998 and Erickson
2001 conducted systematic reviews to assess the incidence of breast cancer related oedema. The included studies assessed its incidence in Europe, Australia and North America. Using different search strategies, Petrek 1998 found eight studies which included incidence and Erickson 2001 found ten, including potentially two studies which were too recent to include in the review by Petrek 1998. Four papers were included in both reviews although one paper was judged to be retrospective by Petrek 1998 and prospective by Erickson 2001. Three methods of assessing lymphoedema were included: volume, limb circumference and self report. The time scale used for follow-up also varied. Petrek 1998 reported incidence figures of 6 to $30 \%$, however, the table used to explain these figures is unclear. Using only axillary dissection papers, in the review by Erickson 2001 a range of 2.4 to $56 \%$ was found. The range in time of follow-up, where available, seemed to result in the wide variety of reported findings. The figures for lymphoedema of the lower limbs were even less reliable yet it appears to be a major problem. In many other cancers (for example melanoma, soft tissue sarcoma and pelvic tumours) the treatment often compromises lymphatic drainage routes. Chronic venous insufficiency is also a major contributory factor in the development of chronic 
lower limb oedema, as is filariasis, a parasitic infection endemic in parts of India and Africa. Moffatt 2003 surveyed healthcare providers in South West London and found a crude prevalence of lymphoedema from any cause of 1.33 per 1000 . The incidence of arm oedema was much higher in women, which reflects the large number of women developing lymphoedema following development of breast cancer.

Lymphoedema can result in significant physical and psychological morbidity. Swelling causes a disproportion in the size of a part of the body and, as such, can both interfere with mobility and affect sufferers' perceptions of themselves (Tobin 1993). In addition to an increase in size of a limb, the affected subcutaneous tissues gradually thicken and fibrose, forming a solid component to the swelling (Foldi 1985; Mortimer 1995). The presence of fibrotic tissue makes it difficult for fluid in the tissues to drain; affected tissues are often described as "woody". This explains why established lymphoedema does not respond to elevation of a limb and why it appears to be more resistant to treatment. Often the more solid limbs are not the biggest in size but, as the fluid is difficult to mobilise, it seems likely that a cycle of further fibrosis is set up. The continued presence of fluid in these areas of hardened tissue provides a stimulus to further thickening. Whether the presence of fibrosis increases the risk of the acute inflammatory attacks to which affected patients are prone is not known.

The management of this condition involves decongesting the reduced lymphatic pathways as a way of reducing the size of the affected limb; encouraging the development of collateral drainage routes; and stimulating the function of remaining patent routes in order to control the swelling long-term (Foldi 1985; Mortimer 1995). Traditional treatments in Europe have focused on the use of physical therapies to reduce and control oedema (Foldi 1985). Complex physical therapy (CPT), using a multi-layer bandaging technique (Badger 2000) and manual lymph drainage (a specific form of massage) are used to reduce oedema, followed by a maintenance regime of strong compression hosiery, regular exercise and careful skin care and hygiene.

In most countries of the world, the standard treatment regime consists of compression hosiery, skin care and exercise. The use of drugs has also gained favour over the last ten years, particularly in Australia and Third World countries (Casley-Smith 1993(1); distance from services and climatic conditions may make the provision and effectiveness of physical therapy more difficult.

A number of drugs have been used for this condition and mainly belong to a group known as benzo-pyrones. Formed from a variety of naturally occurring substances, benzo-pyrones may be plant extracts, semi-synthetic preparations or wholly synthetic (Ramalet 2000). They can be divided into alpha-benzo-pyrones, which include the coumarin derivatives; and gamma-benzo-pyrones, which are the flavonoids (Ramalet 2000). Gamma-benzo-pyrones can be further subdivided into flavones and flavonols, such as diosmin, rutin etc.; and flavanes (flavanones) such as hesperidin.

Developed originally for use in vascular medicine, benzo-pyrones act by reducing vascular permeability (Cesarone 1992; Ramalet 2000; Roztocil 1993) and reduce the amount of fluid forming in the subcutaneous tissues. Among the most commonly used benzo-pyrones are: micronized purified flavanoid fraction (MPFF) known as Daflon, which is a semi-synthetic preparation from diosmin; oxerutins, such as Paroven and Venorutin; escins (horsechestnut) such as Venastat and Reparil; coumarins such as 5,6, benzo-alpha-pyrone and Lodema; and ruscogenin (butcher's broom) combined with hesperidin, as in Cyclo 3 Fort. Much higher doses of these drugs are used in the treatment of lymphoedema than in venous disease. There is a belief that, as a result of reducing fluid filtration into the tissues, the drugs have some beneficial effect on pain and discomfort in the swollen limb. Claims are also made for the ability of these drugs to increase macrophage activity (Hoult 1996), encouraging the lysis of extracellular protein which in turn reduces the formation of fibrotic tissue in the lymphoedematous limb (Piller 1976(1). There have been concerns about the use of substances such as coumarin long-term, particularly in the doses used to treat lymphoedema. These doses tend to be higher than those recommended in venous disease. Australia has withdrawn coumarin from use because of concerns about liver to

\section{O B JE C T IVES}

1.To assess the effectiveness of benzo-pyrones, compared to placebo, in reducing limb volume in lymphoedematous limbs

2.To assess the relative effectiveness of different benzo-pyrones in reducing limb volume in lymphoedematous limbs

3. To assess the impact of benzo-pyrones on the quality of subcutaneous tissues in lymphoedematous limbs

4.To assess the effect of benzo-pyrones on pain or discomfort in lymphoedematous limbs

5.To assess the impact of benzo-pyrones on the lymphoedema patient's quality of life

6. To assess the incidence of adverse effects associated with benzopyrones

\section{METHODS}

\section{Criteria for considering studies for this review}

\section{Types of studies}


Only randomised controlled clinical trials were included in this review. If crossover designs were used, the data were analysed up to the point of crossover.

\section{Types of participants}

Studies that recruited adults (18 years of age and older) with a diagnosis of lymphoedema.

Lymphoedema was defined as clinically detectable oedema from a peripheral cause and of greater duration than 3 months.

For patients with unilateral oedema, the increase in limb volume of the swollen limb had to be at least $10 \%$ above that of the contralateral normal limb volume. This cut-off point is based on information regarding the per cent difference in volume between left and right limbs in the normal population, which can be as high as 8 or $9 \%$ (Sitzia 1997). There is no objective means of assessing bilateral lymphoedema and the presence of swelling was determined by taking a patient history, and by subjectively assessing the feel and appearance of the affected skin and subcutaneous tissues, including the use of Stemmer's sign, the inability to pick up a fold of skin at the base of a digit.

Non-cancer and cancer patients could be included; cancer patients should have completed their cancer treatment at least six months before entering the trial and be without evidence of recurrent malignant disease when going into the trial. Participants could have received prior standard treatment (i.e. have been fitted with a compression garment and followed a regimen of skin care and exercise) but should not have had a course of Complex Physical Therapy (i.e. multi-layer bandaging) within the six months leading up to their inclusion in the trial.

\section{Types of interventions}

Any trial that tested one of the following regimes was included for consideration:

1. Paroven or beta-hydroxyethylrutoside or Venoruton versus placebo;

2. Coumarin or 5,6 Benzo-alpha-pyrone or Lodema versus placebo;

3. Venastat or Reparil versus placebo;

4. Cyclo 3 Fort versus placebo;

5. Daflon (MPFF) versus placebo

The above regimens could include standard physical treatment, as previously defined i.e. compression hosiery, exercise and skin care, as long as it was given to both groups.

The route of administration could be either oral or intravenous for the different drugs (for example Cyclo 3 Fort cannot be taken orally) but the route had to be the same for the one drug. Followup of at least three months was required as it is believed that many benzo-pyrones, in particular Paroven, may take up to six months to have any effect. It is possible that other benzo-pyrones may take less time to take effect and in order not to risk excluding trials of high quality that may have reported shorter follow-up periods, a minimum of three months was selected for this review.

\section{Types of outcome measures}

The main outcome measure was the measurement of the volumes of limbs - volume could be measured in litres or millilitres by:

a) water displacement;

b) electronic volometer;

c) or calculated from surface measurements.

Other physical benefits to be noted included:

a) improvement in pain / discomfort scores (using validated methods of assessment such as visual analogue scales);

b) changes in tonometry assessments of the affected tissues (where a validated method has been used such as that described by Bates 1994)

c) reduction in the number of attacks of cellulitis;

d) increase in strength and function of a limb if assessed using validated measures or scales;

e) quality of life;

f) psychological morbidity;

g) adverse events.

Psychological benefits could be assessed using validated scales such as:

a) Hospital Anxiety and Depression scale (HAD)

b) Psychosocial Adjustment to Illness Scale (PAIS)

c) A disease specific quality of life scale (e.g. Wesley Clinic Lymphoedema Scale Mirolo 1995)

Records of adverse effects relating to the drugs were also to be kept as both short-term and long-term adverse events were to be reported.

\section{Search methods for identification of studies}

The Cochrane Breast Cancer Group register was searched (September 2003) using the search strategies of the Cochrane Breast Cancer group as outlined in the The Cochrane Library. The Cochrane Central Register of Controlled Trials (The Cochrane Library, Issue 4, 2003), MEDLINE, EMBASE, CINAHL, UnCover, PASCAL, SIGLE, reference lists produced by The British Lymphology Society, the National Research Register (NRR) and The International Society of Lymphology congress proceedings were searched (from the date of inception of the database until September 2003).

The reference lists in all the retrieved papers were scanned for relevant studies. International experts in the field were contacted to see if they held any unpublished data, as were those found to be presenting relevant papers in the conference proceedings.

Non-English papers were included.

The terms used for the searches were as follows:

Lymph?edema NOT animal

a) AND benzo?pyrone*; 
b) OR coumarin;

c) OR Lodema

d) OR (5,6 benzo-[alpha]-pyrone);

e) OR beta?hydroxyethylrutoside*;

f) OR Paroven;

g) OR Venoruton;

h) OR rutoside*;

i) OR Daflon

j) OR MPFF

k) OR Reparil

l) OR Venastat

m) OR Cyclo 3 Fort;

n) OR ruscogenin

\section{Data collection and analysis}

One reviewer was designated to scan the titles and abstracts of the papers identified (CB). Those clearly not relevant, based on a reading of the abstract, were excluded immediately; if no abstract was available then a more detailed reading of the paper was made. If there was any doubt about the eligibility of a paper it was not excluded at this stage.

Those papers thought to be relevant were then assessed for eligibility according to the set criteria by two reviewers (CB, NP) working independently. An eligibility form was designed to aid the selection of papers. All the screening of the papers was carried out blinded, i.e. with the authors' names blanked out and with the papers allocated a number with the letter "D" for the "Drug" used in front of it, (D1, D2 etc.). A third reviewer (KS) was appointed to resolve any disagreement over the inclusion of any particular study.

A data extraction form was designed and piloted before being used. Data extraction was duplicated by the second reviewer.

The following data were extracted from the selected studies:

1. details of participants including demographic characteristics, source of recruitment, site of oedema, cause of oedema, duration of oedema, relevant co-existing medical conditions;

2. the type and treatment of any cancer including the patient's cancer status at the time of the trial (where relevant);

3. the experimental and control interventions including drug, dosage, route of administration; compliance with allocated treatment; description of the physical treatments used, if any, and confirmation that CPT had not been used in the six months before the trial;

4. long-and short- term adverse events separately for each of the different drugs (if adverse events were not reported the authors would were contacted)

5. the homogeniety of the the two treatment groups e.g. in terms of severity of oedema at the start of the trial;

6 . methods of assessment of limb volume and other relevant outcomes such as tonometry scores, etc;
7. details of any financial support that might introduce a conflict of interest;

8. the numbers of participants allocated to each group and the numbers lost to follow-up, or excluded with the reasons why.

Any data from different psychological scales, methods of assessing the quality of tissues or pain and discomfort etc. were analysed separately. Adverse events were reported separately for the different drugs. Results from the trials were analysed according to the followup time.

Analysis was by intention to treat if the data were presented as such. Continuous data, such as the percentage reduction in excess limb volume or reduction of volume in litres and any scales used to assess symptoms such as pain, were summarised as standardised means and standard deviations. These data were plotted to detect the presence of any skew in reporting. For dichotomous data, such as the presence or absence of a symptom, the impact of treatment was expressed as relative risks together with $95 \%$ confidence intervals. Separate comparisons were made for each of the types of interventions. Meta-analysis was attempted where there were sufficient trials reporting the same comparison. Standardised mean differences were combined for the continuous data. Where there was sufficient homogeneity, the fixed effect model was used to combine the relative risks for the dichotomous data; where significant heterogeneity was detected, possible explanations were explored and the random effects model used. Sensitivity analyses were conducted of the effects of cause and site of oedema.

If significant heterogeneity was found then the following were investigated as possible explanations:

1. type of drug;

2. dosage of drug;

3. duration of therapy;

4. geographical differences;

5. severity of oedema;

6. whether upper or lower limb oedema;

7. cause of oedema;

8. duration of oedema.

Funnel plots were plotted in order to investigate the possibility of publication bias.

\section{RES U L T S}

\section{Description of studies}

See: Characteristics of included studies; Characteristics of excluded studies.

From the review of titles 63 papers were considered for full review. Of these, 15 were included in the review (see table of Characteristics of included studies), one excluded (Clodius 1978) and 47 were found to be ineligible. 


\section{Review or summary papers}

Details of the nine papers reviewing or summarising trials appear in Additional Table 1. All but two of these, Olszewski 2000 and Wadworth 1992, involved the same author, (Casley-Smith).

Table 1. Ineligible papers reporting summaries or reviews of trials

\begin{tabular}{ll}
\hline Study ID & Summary / Review \\
\hline Olszewski 2000 & Summarises 4 trials, only 1 relates to lymphoedema. \\
\hline Wadworth 1992 & Reviews 3 trials relating to lymphoedema, 1 of which is an open-study \\
\hline Casley-Smith 1999 & Claims to review "fifty trials of 4 benzo-pyrones in the treatment of lymphoedema" \\
\hline Casley-Smith 1992 & Summarises 4 trials \\
\hline Casley-Smith 1993(6) & Summarises 3 trials \\
\hline Casley-Smith 1993(4) & Summarises 3 trials \\
\hline Casley-Smith 1990 & Summarises 2 trials \\
\hline Casley-Smith 1991 & Summarises 4 trials \\
\hline Casley-Smith 1993(5) & Summarises 2 trials \\
\hline
\end{tabular}

In a paper describing the use of micronized purified flavonoid fraction (MPFF or Daflon $500 \mathrm{mg}$ ) in oedema, Olszewski 2000 summarised four trials of the drug. Only one of these studied the effect of MPFF on lymphoedema; the others investigated its use in chronic venous insufficiency. Olszewski reported that the lymphoedema study (Pecking 1997) was a randomised controlled trial of 104 women with upper limb oedema following treatment for breast cancer. Lymphoscintigraphy was used to assess lymph flow at the start and end of the six month trial. Changes in limb volume, as measured every two months, was the other outcome. A subset of 24 patients with severe oedema were analysed separately and "results showed a significant improvement in the lymphoscintigraphic parameters in the MPFF group". The author omitted to report that Pecking found no significant differences between either the lymphoscintigraphy parameters or the limb volumes of the MPFF and placebo groups at any point during the trial; the differences emerged only in the subset with severe oedema. The only area where a significant difference was detected in all those who completed the trial was in an analysis of symptoms: a significant reduction in the symptom of heaviness was found in the MPFF group $(n=46)$ compared to the placebo group $(n=48)$ and a significant reduction in discomfort in both MPFF $(n=45)$ and placebo $(n=48)$ groups. The review failed to discuss adequately the method of randomisation or blinding and no standard deviations or confidence intervals were reported. The review also failed to report information about withdrawals (only 94 patients completed the study) or adverse events, which were reported in six patients in the placebo group and eight in the MPFF group.

In a review of the pharmacology of hydroxyethylrutosides (HR) and their therapeutic efficacy in venous insufficiency and related disorders, Wadworth 1992 included a section on the use of these drugs in lymphoedema. The authors reviewed two reports of randomised, double-blind, cross-over, placebo-controlled studies ( Piller 1988, Taylor 1993) investigating HR 3g per day over 6 months in a combined total of 48 patients with upper limb lymphoedema following treatment for breast cancer and 14 with lower 
limb lymphoedema. In their review of (Piller 1988) they failed to point out that there was no information provided about the stage at which the 10 withdrawals from the study were made: whether they were before or after the crossover point. They reported that HR "reduced limb volume and circumference, increased limb softness and reduced elevated skin temperatures (all changes significantly different vs placebo...)". Treatment also "significantly improved the sensation of limb swelling, 'bursting' pain, heaviness, tension and mobility". No figures were provided for any of these outcomes and no mention made of the fact that all the data in the original paper had to be deduced from graphs. Apparently $97 \%$ of patients "reported increased general well-being" while on HR versus $4 \%$ on placebo and $70 \%$ of patients preferred the active treatment. In their report of the second trial (Taylor 1993) the authors stated that HR "reduced arm volume by about $10 \%$ ( $\mathrm{p}<0.05$ vs baseline)". Once again this was a crossover trial with no information about when the withdrawals from the study occurred. A third trial Braun 1971 reviewed by Wadworth and Faulds found an enhanced effect from the benefits of physiotherapy given to 59 patients after treatment for breast cancer, when HR $600 \mathrm{mg}$ /day was given to 32 of the patients over four months; but this was an open study, not a blinded trial. The authors of the review concluded that hydroxyethylrutosides had "...improved signs and symptoms of patients with lymphoedema" and that the recommended dose in such cases is $3 \mathrm{~g} /$ day. They stated that while the compound was well tolerated when used for up to six months, claiming that "most reported events have been mild and transitory", less was known about its long-term use.

In the remaining seven papers (Casley-Smith 1990, Casley-Smith 1991, Casley-Smith 1992, Casley-Smith 1993(4), Casley-Smith 1993(5), Casley-Smith 1993(6), Casley-Smith 1999), CasleySmith reviewed a number of trials of benzopyrones. The largest of these reviews (Casley-Smith 1999) was said to include 50 clinical trials. To arrive at this number the trials were categorised according to their design and then split according to the grade of lymphoedema they studied, treating each of these groups as separate trials. Thus three of the trials were counted more than once.

In many of these review papers there were problems concerning the interpretation of the numbers of patients involved (nowhere was the number randomised and the number withdrawn or excluded reported) and also in the interpretation of the results. There were inaccuracies, for example in the account of one HR trial (Taylor 1993): the numbers of participants were reported as 44 when that was the number approached for randomisation and the number actually randomised was 31; in another (Piller 1988) the number of patients studied was 80 when the paper gave a figure of 50 patients randomised; in yet another (Mortimer 1995), a figure of 19 patients, when the number actually randomised was 46 . In the MPFF study (Pecking 1997) 104 patients were randomised but data are only provided for a subset of 24 with severe oedema who were subjected to a separate analysis; the results on 20 participants were reported without adding that the authors found no difference between the active and placebo groups. In addition to inaccuracies and lack of information, different conclusions were drawn, on occasion from those of the authors of the papers. In one (Taylor 1993 ), a $14 \%$ reduction in oedema due to the active drug was reported while the authors themselves reported at most a $10 \%$ reduction and described this reduction as clinically unimportant . In another (Mortimer 1995), a 30\% reduction was reported when the most that could be deduced from the graphs in this paper (which were the only source of information) was a reduction of $4 \%$.

In Casley-Smith 1999, after summarising the results of the trials, a meta-analysis was carried out, including non-randomised and open trials, followed by a series of sensitivity analyses excluding those non-double blind trials and non-peer reviewed papers. The conclusions of the review were that the results were robust and that benzo-pyrones were responsible for an overall reduction over one year of $55-71 \%$, depending on the severity of oedema.

\section{Risk of bias in included studies}

The 15 studies included in the review are summarised by intervention in Additional tables 02 to 06.

Included studies investigating $\mathrm{O}$-(b-hydroxyethyl)-rutoside (oxerutin, HR) studies

Three randomised trials testing HR Table 2 were identified. Two ( Mortimer 1995, Taylor 1993) were conducted in England one (Piller 1988) took place in Australia. Two were of a crossover design with no washout period (Piller 1988, Taylor 1993); the third was a parallel group trial (Mortimer 1995). The Australian paper reported the method of randomisation, saying that separate randomised lists were used for arm and leg patients, but omitted to say how allocation was concealed. Information was available from one set of authors (Mortimer 1995), who confirmed that central telephone randomisation was used and that blinding was based on a pharmacy scheme. The other two papers gave no details of blinding other than to state, in one of them (Piller 1988), that capsules were supplied by the pharmacy according to randomised lists. The HR treatment periods were six months in all three trials.

Table 2. O-(b-Hydroxyethyl)-rutoside ( oxerutin, HR) studies

\begin{tabular}{l|l|l|}
\hline Study ID & Methods & Interventions
\end{tabular}


Table 2. O-(b-Hydroxyethyl)-rutoside ( oxerutin, HR) studies (Continued)

\begin{tabular}{|c|c|c|c|c|}
\hline Mortimer 1995 & 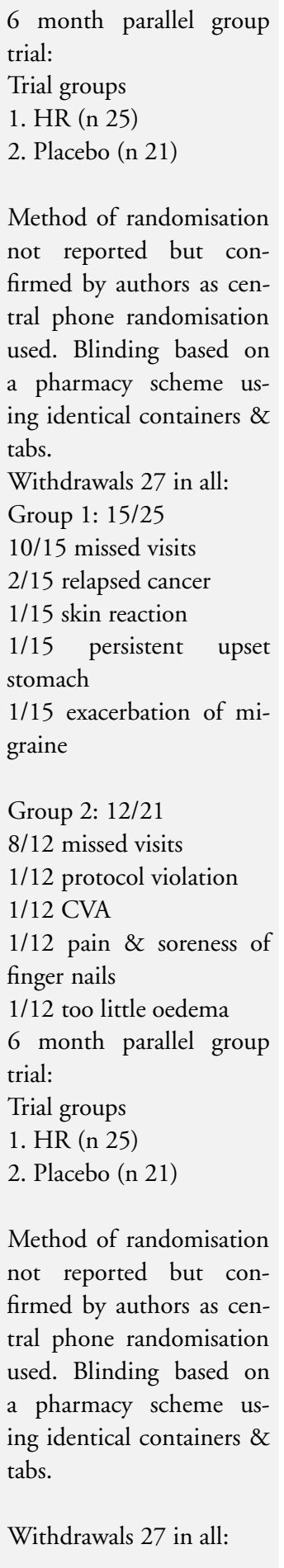 & $\begin{array}{l}46 \\
\text { patients randomised from } \\
\text { Lymphoedema Clinic } \\
\text { All female, upper limb } \\
\text { only, all breast ca-related } \\
\text { No details on age, duration } \\
\text { of oedema or cancer treat- } \\
\text { ment } \\
\text { Degree of oedema at start } \\
\text { by group - mean (no SD): } \\
\text { 1. } 42 \% \text { Excess Volume } \\
\text { 2. } 38 \% \text { Excess Volume }\end{array}$ & $\begin{array}{l}6 \text { months HR } 3 g \text { daily ver- } \\
\text { sus } \\
6 \text { months placebo daily. } \\
\text { All patients continued } \\
\text { with standard compression } \\
\text { treatment, skin care and } \\
\text { exercises. }\end{array}$ & $\begin{array}{l}\text { Calculated swollen / nor- } \\
\text { mal limb volumes from } \\
\text { surface measurements us- } \\
\text { ing frustrum of a cone for- } \\
\text { mula } \\
6 \text { symptoms assessed on } 5 \\
\text { point scale and on Visual } \\
\text { Analogue Scales } \\
\text { Pain assessed on McGill } \\
\text { pain questionnaire }\end{array}$ \\
\hline
\end{tabular}


Table 2. O-(b-Hydroxyethyl)-rutoside (oxerutin, HR) studies (Continued)

\begin{tabular}{|c|c|c|c|c|}
\hline & $\begin{array}{l}\text { Group } 1: 15 / 25 \\
10 / 15 \text { missed visits } \\
2 / 15 \text { relapsed cancer } \\
1 / 15 \text { skin reaction } \\
1 / 15 \text { persistent upset } \\
\text { stomach } \\
1 / 15 \text { exacerbation of mi- } \\
\text { graine } \\
\text { Group } 2: 12 / 21 \\
8 / 12 \text { missed visits } \\
1 / 12 \text { protocol violation } \\
1 / 12 \text { CVA } \\
1 / 12 \text { pain \& soreness of } \\
\text { finger nails } \\
1 / 12 \text { too little oedema }\end{array}$ & & & \\
\hline Taylor 1993 & $\begin{array}{l}12 \text { month crossover trial } \\
\text { Trial groups: } \\
\text { 1. HR first (n 16) } \\
\text { 2. Placebo first (n 15) } \\
\text { Method of randomisation } \\
\text { and blinding not reported } \\
\text { Withdrawals } 9 \text { in all: } \\
\text { Group } 1=5 / 16 \\
1 / 5 \text { possible adverse reac- } \\
\text { tion } \\
1 / 5 \text { stress of trial } \\
1 / 5 \text { progression of cancer } \\
2 / 5 \text { family stress } \\
\text { Group } 2=4 / 15 \\
1 / 4 \text { possible adverse reac- } \\
\text { tion } \\
1 / 4 \text { family stress } \\
1 / 4 \text { viral hepatitis } \\
1 / 4 \text { progression of cancer } \\
\text { Not stated whether with- } \\
\text { drawals occurred before or } \\
\text { after crossover } \\
\text { Adverse events see above }\end{array}$ & $\begin{array}{l}44 \text { approached for ran- } \\
\text { domisation, } 31 \text { were ran- } \\
\text { domised; } \\
\text { all patients from Lym- } \\
\text { phoedema Clinic; } \\
\text { unilateral upper limb only; } \\
\text { all but } 1 \text { breast ca-related. } \\
1 \text { male } 30 \text { female } \\
\text { Degree of oedema at start } \\
\text { by groups - mean \% ExV } \\
\text { (no SD reported): } \\
\text { 1. } 35 \% \\
\text { 2. } 30 \% \\
\text { Duration of oedema by } \\
\text { groups - mean (SD calcu- } \\
\text { lated from SE): } \\
\text { 1. } 7.9 \text { yrs (6.0) } \\
\text { 2. } 7.9 \text { yrs (5.4) } \\
\text { Age by groups - mean (SD } \\
\text { calculated from SE) } \\
\text { 1. } 56.4 \text { yrs (18.7) } \\
\text { 2. } 60.3 \text { yrs (10.0) }\end{array}$ & $\begin{array}{l}6 \text { month HR } 3 \text { g daily, } \\
6 \text { month placebo. } \\
\text { All patients continued } \\
\text { their usual physical treat- } \\
\text { ment regime of compres- } \\
\text { sion sleeves exercise, mas- } \\
\text { sage \& skin care. }\end{array}$ & $\begin{array}{l}\text { Calculated swollen \& nor- } \\
\text { mal limb volumes from } \\
\text { surface measurements us- } \\
\text { ing cylinder formula. } \\
\text { Measured tissue tone by } \\
\text { Tonometry. Expressed as } \\
\% \text { difference in mm moved } \\
\text { by weight of tonometer be- } \\
\text { tween swollen \& normal } \\
\text { limbs } \\
\text { Assessed joint mobility by } \\
\text { scoring functional move- } \\
\text { ments } \\
\text { Assessed pain using McGill } \\
\text { Pain Quest. and VAS } \\
\text { scores }\end{array}$ \\
\hline
\end{tabular}


Table 2. O-(b-Hydroxyethyl)-rutoside (oxerutin, HR) studies (Continued)

\begin{tabular}{|c|c|c|c|c|}
\hline Piller 1988 & $\begin{array}{l}12 \text { month crossover trial: } \\
\text { Trial groups - } \mathrm{n} \text { after with- } \\
\text { drawals: } \\
\text { 1. Upper limb HR 1st } \\
\text { (n13) } \\
\text { 2. Upper limb placebo 1st } \\
\text { (n13) } \\
\text { 3. Lower limb HR 1st (n7) } \\
\text { 4. Lower limb placebo 1st } \\
\text { (n7) } \\
\text { Upper and lower limbs } \\
\text { randomised according to } \\
\text { separate lists. No details on } \\
\text { blinding. } \\
\text { Withdrawals / exclusions: } \\
10 \text { in all } \\
10 / 10 \text { hospital too far } \\
\text { away } \\
\text { Not stated whether with- } \\
\text { drawals occurred before or } \\
\text { after crossover nor which } \\
\text { group they came from } \\
\text { So } 40 \text { patients completed } \\
\text { trial } \\
\text { Adverse events: } 1 / 40 \\
1 \text { in placebo grp had nau- } \\
\text { sea \& giddiness; not stated } \\
\text { whether upper or lower } \\
\text { limb }\end{array}$ & 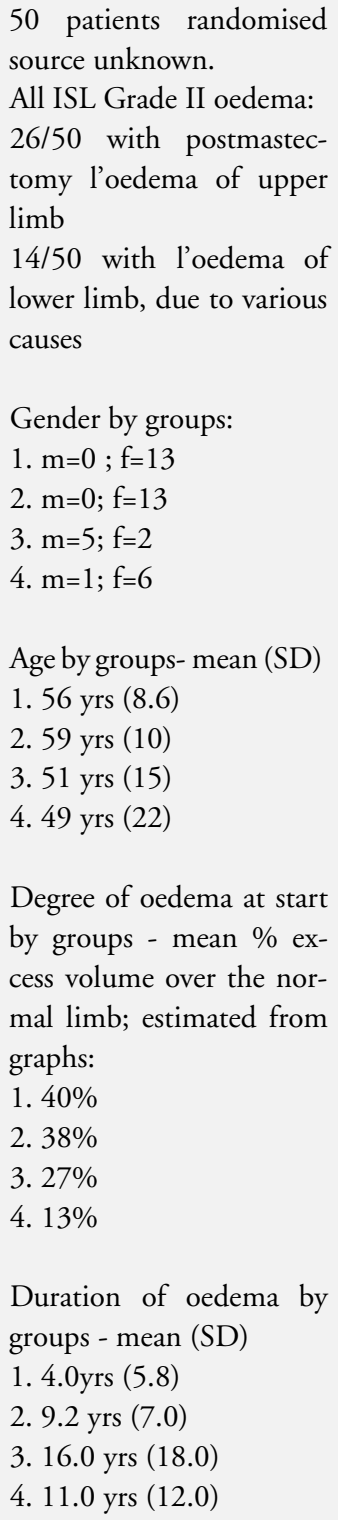 & $\begin{array}{l}6 \text { month HR } 3 g \text { daily, } v \\
6 \text { month placebo - no de- } \\
\text { tails given } \\
\text { All other treat- } \\
\text { ments such as compression } \\
\text { hose stopped } 1 \text { month be- } \\
\text { fore trial. }\end{array}$ & $\begin{array}{l}\text { Measured limb volume by } \\
\text { water displacement; (also } \\
\text { circumferences) } \\
\text { Physical symptoms \& feel- } \\
\text { ing of well-being scored on } \\
5 \text { point scale from much } \\
\text { worse to improved } \\
\text { Tissue tone measured by } \\
\text { Tonometry at } 2 \text { sites on } \\
\text { each limb (proximal \& dis- } \\
\text { tal)- the higher the figure } \\
\text { the softer the tissues } \\
\text { Skin temperature mea- } \\
\text { sured by digital skin ther- } \\
\text { mometer - } 1 \text { electrode } \\
\text { placed on swollen limb \& } \\
1 \text { on normal limb; reported } \\
\text { as \% difference between } \\
\text { them }\end{array}$ \\
\hline
\end{tabular}

All three studies tested HR against placebo and all three used a dose of $3 \mathrm{~g}$ daily. In two of the trials (Mortimer 1995; Taylor 1993), patients continued to follow their usual physical treatment regimen of compression hosiery, exercises, skin care, and in the case of one Taylor 1993, self-massage throughout the period of the trial. In the third trial (Piller 1988), all treatments were stopped one month before the trial.

Two of the trials (Mortimer 1995; Taylor 1993) looked at the effect of the drug on unilateral upper limb lymphoedema: all but one of the patients in these trials had breast cancer-related oedema.
The third trial (Piller 1988), looked at unilateral lower limb lymphoedema (primary and secondary to trauma and infection) in addition to breast cancer related upper limb lymphoedema. No details of any cancer treatment given to the patients were reported with the exception of the one male patient with upper limb lymphoedema resulting from squamous cell carcinoma of the hand, in Taylor 1993. Patients with active disease at the start of the trials were excluded in two of the trials but the third (Mortimer 1995) included nine such patients. The original plan to stratify for active disease in the latter trial was dropped due to the small numbers. 
A total of 127 patients were randomised across all three studies. Only one report (Taylor 1993) stated the number approached for randomisation $(\mathrm{n}=44)$ and the number subsequently randomised $(\mathrm{n}=31)$. Of the total 127 randomised, the investigators either excluded or withdrew 56 participants leaving a total of 81 patients included in the analyses. Neither of the crossover trials stated whether withdrawals and exclusions occurred before or after the point of crossover, thus allowing the possibility of additional bias in the results.

Included studies investigating Ruscus aculeatus and hesperidin methyl chalcone (Cyclo 3 Fort) studies

We found one randomised trial (Cluzan 1990), testing Cyclo 3 Fort (Table 3), which was conducted in France. Participants were stratified according to degree of oedema as determined by differences in circumference between limbs prior to randomisation. Mild oedema was defined as a difference in circumference of the arm (a term usually taken to refer to the upper arm but which was not used consistently in this sense by the authors) of greater than 2 $\mathrm{cms}$ but less than $5 \mathrm{cms}$; and moderate oedema, of greater than 5 $\mathrm{cms}$ but less than $8 \mathrm{cms}$. The trial had a duration of three months.

Table 3. Ruscus aculeatus $\&$ hesperidin methyl chalcone (Cyclo 3 Fort) studies

\begin{tabular}{|c|c|c|c|c|}
\hline Study ID & Methods & Participants & Interventions & Outcomes \\
\hline Cluzan 1996 & $\begin{array}{l}3 \text { month trial in Paris } \\
\text { Subjects stratified accord- } \\
\text { ing to degree of oedema: } \\
\text { mild / moderate; then } \\
\text { randomised to active or } \\
\text { placebo } \\
\text { Method of randomisation } \\
\text { \& blinding not reported } \\
\text { Trial groups: } \\
\text { 1. Mild Active (n12) } \\
\text { 2. Mild Placebo (n12) } \\
\text { 3. Moderate Active (n15) } \\
4 . \text { Moderate Placebo (n18) } \\
\text { Withdrawals / exclusions } \\
\text { reported according to treat- } \\
\text { ment: } \\
\text { Active groups } 4 / 27 \\
\text { 1/4 lost to f-up } \\
2 / 4 \text { adverse reactions } \\
1 / 4 \text { poor compliance } \\
\text { Placebo groups } 5 / 30 \text { : } \\
1 / 5 \text { lost to f-up } \\
2 / 5 \text { lymphangitis } \\
2 / 5 \text { poor compliance }\end{array}$ & $\begin{array}{l}57 \text { patients from Lymphol- } \\
\text { ogy Unit; } \\
\text { all female; } \\
\text { all with upper limb; } \\
\text { all breast ca-related } \\
\text { oedema. } \\
\text { Degree of oedema at start } \\
\text { not stated } \\
\text { Duration of oedema not } \\
\text { stated } \\
\text { Age not stated except that > } \\
18 \text { yrs } \\
\text { No details of cancer treat- } \\
\text { ment stated }\end{array}$ & $\begin{array}{l}\text { Cyclo } 3 \text { Fort (C3F) } 3 \text { caps } \\
\text { tds } \\
\text { Versus } \\
\text { Placebo } 3 \text { caps tds } \\
\text { plus MLD } 2 \mathrm{x} \text { week for } \\
\text { those who were already re- } \\
\text { ceiving it. No details on the } \\
\mathrm{n} \text { in each group receiving } \\
\text { MLD }\end{array}$ & $\begin{array}{l}\text { Calculated limb volume } \\
\text { from surface measurements } \\
\text { using formula for trun- } \\
\text { cated cones. Reported as } \\
\% \text { change in excess volume } \\
(\mathrm{ExV}) \\
\text { No baseline data reported }\end{array}$ \\
\hline
\end{tabular}


Table 3. Ruscus aculeatus $\&$ hesperidin methyl chalcone (Cyclo 3 Fort) studies (Continued)

\author{
Adverse events \\ By Active / Placebo group: \\ 1. C3F 2/27 GI upset \\ 2. Placebo $2 / 30$ infection
}

Patients were recruited from a lymphology unit. All were adult females with unilateral, upper limb oedema following treatment for breast cancer. No details of the cancer treatment were reported nor were details of the duration of oedema. They were receiving manual lymph drainage treatment before the trial and continued during the trial, on a twice weekly regimen; otherwise no other treatments were given.

Cyclo 3 Fort (C3F) was tested against placebo (three capsules three times a day). A total of 57 patients were randomised (the number approached for randomisation was not stated). Of these, 27 were randomised to $\mathrm{C} 3 \mathrm{~F}$ ( 12 with mild oedema, 15 with moderate) and 30 were randomised to placebo (12 with mild oedema, 18 with moderate). Nine patients were later excluded or withdrew (4 C3F, 5 placebo). Two patients in the C3F group were withdrawn at one month and again at two months because of adverse nausea and abdominal pain. It was not stated at what stage of the trial the remaining five patients dropped out.

\title{
Included studies investigating diosmin plus hesperidin
} (Daflon 500mg) study

We found one randomised trial testing MPFF, in the form of micronised diosmin or Daflon 500mg (Pecking 1997; Table 4). This trial was conducted in France. Participants were randomised to one of two groups: active or placebo. The method of randomisation was not reported nor the method of blinding. The trial lasted six months.

Table 4. Diosmin + hesperidin (Daflon $500 \mathrm{mg}$ ) study

\begin{tabular}{|c|c|c|c|c|}
\hline Study ID & Methods & Participants & Interventions & Outcomes \\
\hline Pecking 1997 & $\begin{array}{l}6 \text { month trial in France } \\
\text { Method of randomisation } \\
\text { \& blinding not reported } \\
\text { Two treatment groups: } \\
\text { 1. Diosmin (n 51) } \\
\text { 2. Placebo (n 53) } \\
\text { Withdrawals / exclusions: }\end{array}$ & $\begin{array}{l}104 \text { patients; } \\
\text { source unknown; } \\
\text { all female; } \\
\text { all with upper limb; } \\
\text { all with breast ca-related } \\
\text { oedema } \\
\text { Degree of oedema at start } \\
\text { not stated }\end{array}$ & $\begin{array}{l}\text { Daflon } 500 \mathrm{mg} \text { x } 2 \text { tabs } \\
\text { daily } \\
\text { versus } \\
\text { placebo x } 2 \text { tabs daily } \\
\text { No other treatment given }\end{array}$ & $\begin{array}{l}\text { Calculated excess limb vol- } \\
\text { ume from surface measure- } \\
\text { ments using truncated cone } \\
\text { formula. } \\
\text { Assessed every } 2 \text { months } \\
\text { but no data provided for } \\
\text { pts other than for a sub- } \\
\text { set of } 24 \text { with "more severe } \\
\text { oedema": }\end{array}$ \\
\hline
\end{tabular}


Table 4. Diosmin + hesperidin (Daflon 500mg) study (Continued)

\begin{tabular}{|c|c|c|}
\hline $\begin{array}{l}10 \text { in all, no reasons given: } \\
\text { 1. } 5 / 51 \\
\text { 2. } 5 / 53 \\
\text { So } 94 \text { completed trial } \\
\text { Adverse events by group } \\
\text { 1. } 8 / 51 \\
\text { 3/8 GI upset } \\
\text { 5/8 miscellaneous } \\
\text { 2. } 6 / 53 \text { : } \\
\text { 4/6 GI upset } \\
2 / 6 \text { miscellaneous }\end{array}$ & $\begin{array}{l}\text { Onset after cancer treat- } \\
\text { ment by group - mean } \\
\text { months (SD) } \\
1.33 .8 \text { (48) } \\
2.35 .1 \text { (39.4) } \\
\text { Duration of oedema in } \\
\text { months at start by group, } \\
\text { mean (SD): } \\
1.46 .8 \text { (59.9) } \\
2.31 .1 \text { (39.4) } \\
\text { Mean (SD) age by group: } \\
1.61 .5 \text { yrs (10.8) } \\
2.57 .3 \text { yrs ( } 9.8) \\
\text { Body weight at start by } \\
\text { group - mean (SD): } \\
1.62 .3 \mathrm{~kg}(8.1) \\
2.63 .3 \mathrm{~kg}(8.6) \\
\text { Surgery (\% of pts) by } \\
\text { group: } \\
1.98 \% \\
2.100 \% \\
\text { Radiotherapy (\% of ots) by } \\
\text { group: } \\
1.82 .4 \% \\
2.90 .6 \% \\
\text { Chemotherapy (\% of pts) } \\
\text { by group: } \\
1.33 .3 \% \\
2.60 .4 \%\end{array}$ & $\begin{array}{l}\text { Used lymphscintigraphy to } \\
\text { measure migration speed of } \\
\text { tracer, clearance and half- } \\
\text { life. } \\
\text { No data provided for the } 94 \\
\text { only for subset of } 24 \\
\text { Assessed discomfort by } \\
\text { VAS. } \\
\text { Heaviness assessed on } 4 \\
\text { point scale. }\end{array}$ \\
\hline
\end{tabular}

Daflon $(500 \mathrm{mg})$ was tested against placebo and no other treatments were given. Women aged 30 to 80 years old were recruited to the study, the source of the subjects is unknown. All had mild to severe unilateral upper limb lymphoedema following treatment for breast cancer. Details of cancer treatment were given: the majority of patients were treated with surgery and radiotherapy and the numbers were balanced between active and placebo groups. Twice as many patients had received chemotherapy in the placebo group.

Of the total 104 patients enrolled in the study, 51 were randomised to Daflon and 53 to placebo. There were 10 withdrawals: five from the active group and five from the placebo group; no information was given about the reasons for the withdrawals nor when they occurred.

Included studies investigating coumarin plus troxerutin (Lysedem, coumarin plus TER, CTR) studies

We found three randomised trials investigating the effects of coumarin and troxerutin (Table 5). Two were conducted in France (Desprez 1985; Cluzan 1996) and one was a multi-centre trial from Spain (Burgos 1999). Each trial randomised participants to one of two trial groups and none of the reports gave details of the method of randomisation or blinding. The French trials were of 9 months (Cluzan 1996) and 18 months (Desprez 1985) duration 
while the Spanish trial lasted 12 months.

Table 5. Coumarin + troxerutin (Lysedem, coumarin +TER, CTR) studies

\begin{tabular}{|c|c|c|c|c|}
\hline Study ID & Methods & Participants & Interventions & Outcomes \\
\hline Cluzan 1990 & $\begin{array}{l}9 \text { month trial in France } \\
\text { Method of randomisation } \\
\text { \& blinding not reported. } \\
\text { Trial groups: } \\
\text { 1. Lysedem (n?) } \\
\text { 2. Placebo (n?) } \\
\text { Withdrawals / exclusions: } 2 \\
\text { in all, no reasons given: } \\
\text { 1. } 1 / \text { ? } \\
\text { 2. } 1 / \text { ? } \\
\text { Yet states } 79 \text { completed } \\
\text { trial } \\
\text { Only } 55 \text { pts had lymph- } \\
\text { scintigraphy data analysed: } \\
\text { 1. } 27 / \text { ? } \\
\text { 2. } 28 / \text { ? } \\
\text { Adverse events } 3 / \text { ? } \\
\text { By group: } \\
\text { 1. } 2 / 2 \text { GI upset } \\
\text { 2. } 1 / 1 \text { GI upset }\end{array}$ & 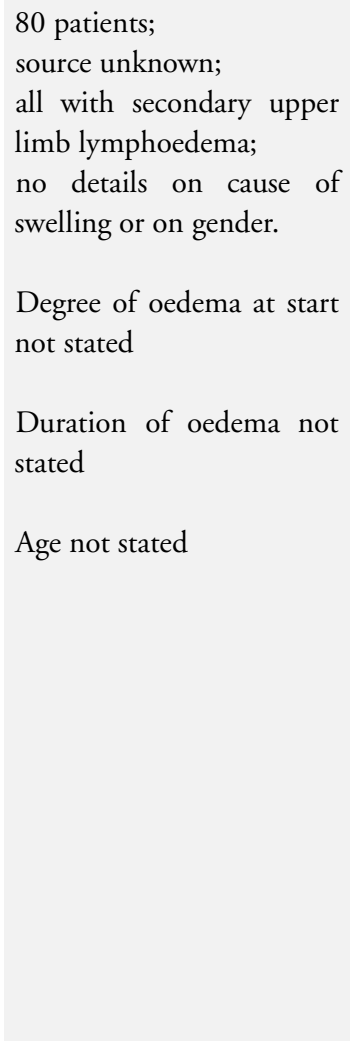 & $\begin{array}{l}\text { Group 1: } \\
9 \text { months Lysedem } 6 \text { tabs } \\
\text { daily, } \\
\text { Group 2: } \\
9 \text { months Placebo } 6 \text { tabs } \\
\text { daily }\end{array}$ & $\begin{array}{l}\text { Volume difference between } \\
\text { normal \& affected limbs } \\
\text { calculated from circumfer- } \\
\text { ences } \\
\text { No baseline data provided } \\
3 \text { point clinical score as- } \\
\text { sessing hardness, heaviness, } \\
\text { pain, subjective improve- } \\
\text { ment - ? reported as mean } \\
\text { combined scores } \\
\text { Lymphscintigraphy param- } \\
\text { eters: } \\
1 / 2 \text { life } \\
\text { Clearance } \\
\text { Speed }\end{array}$ \\
\hline Desprez 1985 & $\begin{array}{l}18 \text { month trial in France } \\
\text { Method of randomisation } \\
\& \text { blinding not stated } \\
2 \text { trial groups: } \\
\text { 1. coumarin for } 18 \text { months } \\
\text { n } 45 \\
\text { 2. placebo for } 6 \text { months } \\
\text { then coumarin for remain- } \\
\text { ing } 12 \text { months n } 46 \\
\text { Withdrawals / exclusions } \\
1 \text { / } 92 \text { - ? at what stage } \\
\text { which group, or why } \\
\text { Adverse effects } \\
\text { Included dizziness, nau- }\end{array}$ & $\begin{array}{l}92 \\
\text { patients all with post-mas- } \\
\text { tectomy lymphoedema } \\
\text { of the upper limb. Presume } \\
\text { all female but not stated. } \\
\text { No differ- } \\
\text { ence between them re age, } \\
\text { affected limb, former treat- } \\
\text { ment, duration of oedema, } \\
\text { circumstances of appear- } \\
\text { ance, infection, subjective } \\
\text { symptoms, "areas of block- } \\
\text { ing“ according to isotope } \\
\text { lymphography }\end{array}$ & $\begin{array}{l}\text { Group } 1 \\
\text { 1. Coumarin + trioxyethyl- } \\
\text { rutin } 9 \text { tabs for first } 6 \mathrm{mths} \text {; } \\
\text { then } 6 \text { tabs up to } 18 \mathrm{mths} \\
\text { Group } 2 \\
\text { 2. Placebo for first } 6 \mathrm{mths} \\
\text { then } 6 \text { tabs coumarin TER } \\
\text { up to } 18 \mathrm{mths}\end{array}$ & $\begin{array}{l}\text { Assessed circum- } \\
\text { ference measurements at } 3 \\
\text { sites: wrist, forearm, arm. } \\
\text { No baseline data given. } \\
\text { Reported \% change in circ } \\
\text { at each site. } \\
\text { Also assessed subjective } \\
\text { symptoms } \\
\text { Episodes of lymphangitis } \\
\text { "Morpho- } \\
\text { logical survey" with isotope } \\
\text { lymphography }\end{array}$ \\
\hline
\end{tabular}


Table 5. Coumarin + troxerutin (Lysedem, coumarin +TER, CTR) studies (Continued)

\begin{tabular}{|c|c|c|c|c|}
\hline & $\begin{array}{l}\text { sea, pollakiuria, pruritus } \& \\
\text { menstrual flow. Details not } \\
\text { given of these by group. } \\
\text { At } 6 \text { mnths all effects by } \\
\text { group: } \\
\text { 1. } \mathrm{n} 6 \\
2 . \mathrm{n} 2 \\
\text { At } 12 \mathrm{mths} \text { by group: } \\
\text { 1. } \mathrm{n} 4 \\
\text { 2. } \mathrm{n} 0 \\
\text { At } 18 \mathrm{mths} \text { none. }\end{array}$ & & & \\
\hline Burgos 1999 & $\begin{array}{l}12 \text { month trial in Spain } \\
\text { Trial groups } \\
\text { Grp 1. Lysedem (n 38) } \\
\text { Grp 2. Lysedem (n 39) } \\
\text { Method of randomisation } \\
\text { and blinding not reported } \\
\text { Withdrawals / exclusions: } \\
24 \text { in all: } \\
\text { Grp } 1 \text {. n } 15 / 38 \\
6 / 15 \text { voluntary } \\
6 / 15 \text { adverse events } \\
3 / 15 \text { lost to f-up } \\
\text { 1/15 protocol violation } \\
\text { (Total = } 16 / 38 \text { not } 15 \text { as } \\
\text { stated) } \\
\text { Grp 2. n } 9 / 39 \\
1 / 9 \text { voluntary } \\
5 / 9 \text { adverse events } \\
1 / 9 \text { lost to f-up } \\
1 / 9 \text { "other causes" } \\
\text { (Total = } 8 / 39 \text { not } 9 \text { as } \\
\text { stated) } \\
\text { States } 53 \text { completed study } \\
\text { "3 more minor protocol vi- } \\
\text { olations" occurred: } \\
\text { Grp } 1 . \text { n } 1 \\
\text { Grp } 2 . \text { n } 2 \\
\text { Adverse events as above }\end{array}$ & $\begin{array}{l}77 \text { patients from } 6 \text { centres: } \\
1 \text { breast unit, } \\
2 \text { rehabilitation depts, } \\
2 \text { depts vascular surgery, } \\
1 \text { oncology dept; } \\
\text { all female; } \\
\text { all with unilateral upper } \\
\text { limb; } \\
\text { all breast ca-related lym- } \\
\text { phoedema; } \\
\text { all ISL Grade } 2 \\
\text { Degree of oedema at start } \\
\text { by group: } \\
\text { Grp } 1.25 .9 \% \\
\text { Grp } 2.22 .6 \% \\
\text { Duration of oedema not } \\
\text { stated but all less than } 10 \\
\text { years } \\
\text { Age by groups - mean (SD) } \\
\text { Grp } 1.52 .0 \text { yrs (8.0) } \\
\text { Grp } 2.52 .8 \text { yrs (7.0) }\end{array}$ & $\begin{array}{l}\begin{array}{l}\text { Group 1. } \\
\text { coumarin }+ \text { troxerutin } \\
\text { (Lysedem) } 90 \text { mg daily }\end{array} \\
\text { Group } 2 \\
\text { coumarin }+ \text { troxerutin } \\
\text { (Lysedem) } 135 \text { mg daily }\end{array}$ & $\begin{array}{l}\text { Volumes of normal \& } \\
\text { affected limbs measured } \\
\text { electronically. Expressed as } \\
\text { changes in excess volume } \\
(\mathrm{ExV}) \\
6 \text { Clinical symptoms as- } \\
\text { sessed by investigator on } 5 \\
\text { point scale: hardness, } \\
\text { heaviness, } \\
\text { neurological signs, } \\
\text { sensation of oedema at } \\
\text { wrist, forearm, upper arm. } \\
\text { Patient \& investigator as- } \\
\text { sessed efficacy of treatment } \\
\text { as: } \\
\text { none, } \\
\text { mild, } \\
\text { moderate, } \\
\text { good, } \\
\text { excellent; } \\
\text { - reported as \% of patients. } \\
\text { No baseline data }\end{array}$ \\
\hline
\end{tabular}


Each of the trials took a different approach to the interventions being studied. Cluzan 1996 tested coumarin (Lysedem six tablets daily) versus placebo; Desprez 1985 tested coumarin plus TER (nine tablets presumably daily) against placebo for 6 months and then allowed both groups to take six tablets of the drug for the remaining 12 months of the trial. No actual doses were given for either of these studies. The Spanish trial (Burgos 1999) compared two different doses of Lysedem (90 mg versus $135 \mathrm{mg}$ ) over 12 months; there was no placebo group.

All three trials studied patients with unilateral upper limb lymphoedema, two (Burgos 1999; Desprez 1985) stated that all patients had oedema following breast cancer treatment; the remaining trial did not report details concerning gender or cause of swelling.

A total of 249 patients were randomised and of these, as 27 were excluded or withdrawn, 222 were included in the analyses. There were discrepancies in two of the studies (Burgos 1999; Desprez 1985), between the numbers withdrawn and the numbers said to have completed the study. None of the reports stated when withdrawals were made.

Included studies investigating $\mathbf{5 , 6}$ benzo-a-pyrone (coumarin, $5,6 \mathrm{BaP})$ studies

We found seven reports of randomised trials of 5,6 BaP (Table 6). Two reports of trials conducted in China, one reported in Chinese (Zhang 1990), and one in English (Chang 1996), were confirmed to be the same trial; another (eighth) report, also in Chinese (Gan 1996), might refer to this same trial but no confirmation has been received from the author and the study is awaiting classification. Two reports of trials conducted in India (Casley-Smith 1993(1); Jamal 1989) appear to refer to the same trial although neither explicitly confirms this link. Another trial was conducted in China (Casley-Smith 1993(2)), while the remaining two trials took place in the United States (Loprinzi 1999) and Australia (Casley-Smith 1993(3)). These latter two trials were of a crossover design both lasting 12 months. The remainder were parallel group trials.

Table 6. 5,6 Benzo-a-pyrone (coumarin, 5,6BaP) Studies

\begin{tabular}{|c|c|c|c|c|}
\hline Study ID & Methods & Participants & Interventions & Outcomes \\
\hline Casley-Smith 1993(1) & $\begin{array}{l}2 \text { year trial conducted in } \\
\text { India } \\
\text { Subjects matched for } \\
\text { grade, duration, age \& } \\
\text { sex in quadruplets then } \\
\text { randomised } \\
\text { Method of randomisa- } \\
\text { tion and blinding not } \\
\text { stated }\end{array}$ & $\begin{array}{l}216 \text { patients bilateral \& } \\
\text { unilateral lymphoedema } \\
\text { of the lower limbs sec- } \\
\text { ondary to filariasis } \\
195 \text { attended for initial } \\
\text { assessment } \\
\text { Mean age by group: } \\
1.50 .5 \text { yrs }\end{array}$ & $\begin{array}{l}\text { Groups } \\
\text { 1. Placebo + placebo } \\
\text { 2. Placebo + } \mathrm{BaP} \\
\text { 3. } \mathrm{DEC}+\text { placebo } \\
\text { 4. } \mathrm{DEC}+\mathrm{BaP} \\
\mathrm{BaP} 2 \times 200 \mathrm{mg} \text { tabs o.d } \\
\text { DEC } 6 \mathrm{mg} / \mathrm{kg} / \text { day } \\
\text { [Was dose calculated in- }\end{array}$ & $\begin{array}{l}\text { Main } \\
\text { outcome was leg volume } \\
\text { assessed } 3 \text { mnthly. } \\
\text { Used water displacement } \\
\text { to measure up to } 30 \mathrm{cms} \\
\text { above the heel ie only to } \\
\text { level of knee. } \\
\text { Looked at } \% \text { Ex V over } \\
\text { normal limb. At least }\end{array}$ \\
\hline
\end{tabular}




\begin{tabular}{|c|c|c|c|c|}
\hline & $\begin{array}{l}\text { 4 trial groups: } \\
\text { 1. placebo + placebo n ? } \\
\text { 2. placebo + } 5,6 \mathrm{BaP} \text { n? } \\
\text { 3. DEC + placebo n ? } \\
\text { 4. DEC + 5,6 BaP n? } \\
\text { Withdrawals / exclusions } \\
\mathrm{n} 21 \text { / } 216 \text { did not appear } \\
\text { for initial assessment; } \\
\mathrm{n} 32 \text { / } 216 \\
\text { excluded } \\
\text { because attended for less } \\
\text { than } 2 \mathrm{f} \text {-up assessments } \\
\mathrm{n} 5 \text { / ? "found BaP tabs } \\
\text { too big to swallow; } \\
\mathrm{n} 20 \text { /? "did not like their } \\
\text { reactions to DEC" } \\
\text { Presume the } 25 \text { above are } \\
\text { part of the } 32 \text { excluded } \\
\text { rather than in addition to } \\
\text { them. } \\
\text { States only } 163 \text { patients } \\
\text { reported on (giving } 183 \\
\text { limbs as some were bilat- } \\
\text { eral) }\end{array}$ & 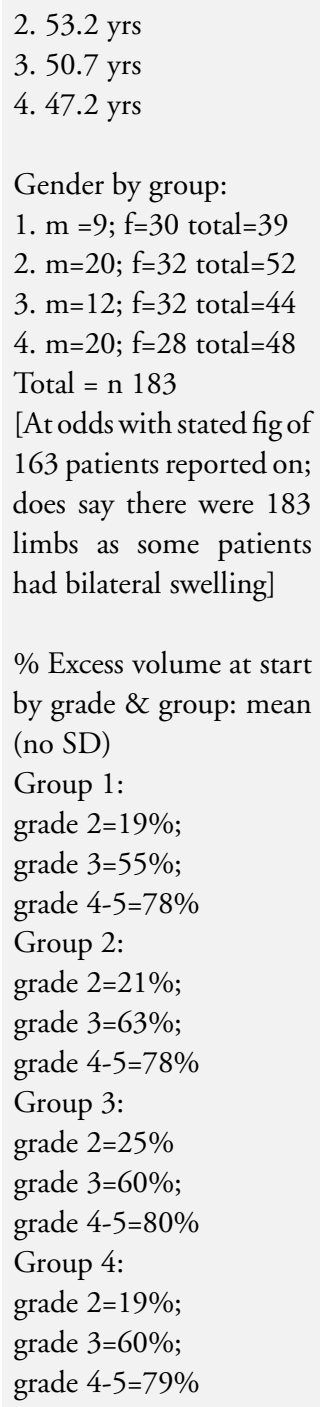 & $\begin{array}{l}\text { dividually for each sub- } \\
\text { ject? } \\
\text { If so did no. of tabs vary? } \\
\text { If so how was it blinded?] } \\
\text { Placebo - no details given } \\
\text { No other treatments } \\
\text { given }\end{array}$ & $\begin{array}{l}20 \text { patients had bilateral } \\
\text { oedema so used means of } \\
\text { normal limbs as control } \\
\text { for bilateral limbs. } \\
\text { Also made circ measure- } \\
\text { ments but did not report } \\
\text { on these } \\
\text { Patients questioned } \\
\text { about symptoms: } \\
\text { Feelings of swelling \& } \\
\text { bursting, Also re sec- } \\
\text { ondary infections } \\
\text { Clinical exam of ulcers }\end{array}$ \\
\hline Jamal 1989 & $\begin{array}{l}2 \text { year trial conducted in } \\
\text { India } \\
\text { Subjects put into groups } \\
\text { matched for grade, age, } \\
\text { sex } \\
\text { Method of randomisa- } \\
\text { tion and blinding not } \\
\text { stated } \\
4 \text { trial groups: } \\
\text { Grp } 1 \text {. placebo + placebo } \\
\text { n } 41\end{array}$ & $\begin{array}{l}169 \text { reported on - ? } \\
\text { whether this was no. ran- } \\
\text { domised. } \\
\text { Only } 20 \text { had completed } \\
\text { the trial. } \\
\text { [Mean f-up reported here } \\
\text { is } 9.3 \text { months] } \\
\text { Pts chosen with "appar- } \\
\text { ently normal" contra-lat- } \\
\text { eral leg }\end{array}$ & $\begin{array}{l}\text { Groups } \\
\text { 1. Placebo + placebo } \\
\text { 2. Placebo + } \mathrm{BaP} \\
\text { 3. DEC + placebo } \\
\text { 4. DEC + BaP } \\
\text { BaP } 2 \times 200 \mathrm{mg} \text { tabs o.d } \\
\mathrm{DEC} 6 \mathrm{mg} / \mathrm{kg} / \text { day } \\
\text { [so was dose calculated } \\
\text { individually for each sub- } \\
\text { ject? } \\
\text { If so did no. of tabs vary? } \\
\text { If so how was it blinded?] }\end{array}$ & $\begin{array}{l}\text { Main } \\
\text { outcome was leg volume } \\
\text { assessed } 3 \text { mnthly. } \\
\text { Used water displacement } \\
\text { to measure. } \\
\text { Looked at \% Ex V over } \\
\text { normal limb.. }\end{array}$ \\
\hline
\end{tabular}




\begin{tabular}{|c|c|c|c|c|}
\hline & $\begin{array}{l}\text { Grp 2. placebo + 5,6 BaP } \\
\text { n } 47 \\
\text { Grp 3. DEC + placebo n } \\
39 \\
\text { Grp 4. DEC + 5,6 BaP n } \\
42\end{array}$ & & Placebo - no details given & \\
\hline Casley-Smith 1993(2) & $\begin{array}{l}2 \text { year trial conducted in } \\
\text { China } \\
\text { Randomised using ran- } \\
\text { dom number tables. } \\
\text { Method of blinding not } \\
\text { stated. } \\
2 \text { trial groups: } \\
\text { 1. coumarin n } 64 \\
2 \text {. placebo n } 40 \\
\text { Subjects } \\
\text { fied for grade of oedema, } \\
\text { duration, sex and age } \\
\text { Chinese authorities ap- } \\
\text { parently } \\
\text { insisted that more peo- } \\
\text { ple be assigned to treat- } \\
\text { ment than placebo. (but } \\
\text { this was only the case } \\
\text { for Grade } 3 \text { oedema - } \\
\text { grades } 1 \& 2 \text { were similar } \\
\text { size.groups) } \\
\text { Withdrawals / exclusions } \\
21 / 104 \text { in all } \\
8 / 21 \text { withdrew from ac- } \\
\text { tive group in } 1 \text { st year: } 6 \\
\text { / } 8 \text { "reasons unconnected } \\
\text { to drug"; } 2 \text { felt they were } \\
\text { cured } \& \text { refused further } \\
\text { treatment ( } 1 \text { at } 1 \text { month, } \\
1 \text { after } 5 \text { months). } \\
13 / 21 \text { withdrew during } \\
2 \text { nd year: } 11 / 13 \text { from ac- } \\
\text { tive group; } 2 / 13 \text { from } \\
\text { placebo group. "all for } \\
\text { reasons unconnected to } \\
\text { trial" } \\
\text { Adverse effects "were }\end{array}$ & $\begin{array}{l}104 \text { patients with uni- } \\
\text { lateral lower limb lym- } \\
\text { phoedema, from around } \\
\text { the Province. } \\
\text { Gender by group: } \\
\text { 1. } \mathrm{m}=31 ; \mathrm{f}=25 \\
\text { 2. } \mathrm{m}=25 ; \mathrm{f}=15 \\
\text { Mean age: } \\
\text { 1. } 55 \text { years } \\
\text { 2. } 58 \text { years } \\
\text { Duration of oedema: } \\
129 \text { years } \\
2.33 \text { years }\end{array}$ & $\begin{array}{l}\text { Group } 1 \\
\text { Coumarin }(5,6 \mathrm{BaP}) 2 \mathrm{x} \\
200 \mathrm{mgs} \text { o.d } \\
\text { Versus } \\
\text { Group } 2 \\
\text { Placebo (? Details) } \\
\text { No other treatments } \\
\text { given }\end{array}$ & $\begin{array}{l}\text { Main outcome limb vol- } \\
\text { ume. } \\
\text { States this was calculated } \\
\text { from surface measure- } \\
\text { ments using truncated } \\
\text { cone method BUT else- } \\
\text { where same authors say } \\
\text { that they only looked at } \\
\text { differences in circumfer- } \\
\text { ences; } \\
\text { authors also imply that } \\
\text { whole leg was measured } \\
\text { (they talk about sum- } \\
\text { ming } 4 \text { truncated cones) } \\
\text { but the reported volumes } \\
\text { are too small for whole } \\
\text { leg and must be below } \\
\text { knee only] } \\
\text { Assessed condition of } \\
\text { skin, hair growth,ulcers, } \\
\text { freq of infection. } \\
\text { Categorised each clinical } \\
\text { feature as none, slight, } \\
\text { mild, moderate, severe }\end{array}$ \\
\hline
\end{tabular}




\begin{tabular}{|c|c|c|c|c|}
\hline & $\begin{array}{l}\text { mild". } 60 \% \text { coumarin pts } \\
\text { felt dizzy / sleepy, } 3 \text { slight } \\
\text { nausea \& diarrhoea, } 2 \\
\text { skin rash. All symp- } \\
\text { toms disappeared after } \\
1 \text { st month. } 5 \text { patients } \\
\text { withdrew with infective } \\
\text { hepatitis (?? When ?? if } \\
\text { included in withdrawals } \\
\text { above) }\end{array}$ & & & \\
\hline Chang 1996 & $\begin{array}{l}12 \text { month parallel group } \\
\text { trial in China; } \\
\text { Method of randomisa- } \\
\text { tion and blinding not } \\
\text { stated } \\
2 \text { trial groups: } \\
\text { Grp 1. coumarin (n 30) } \\
\text { Grp 2. placebo (n } 30) \\
\text { Stratified for grade of } \\
\text { oedema, age, sex, dura- } \\
\text { tion of oedema, cause of } \\
\text { oedema. } \\
\text { Withdrawals - none re- } \\
\text { ported }\end{array}$ & $\begin{array}{l}60 \text { patients, source un- } \\
\text { known (China). } 23 \text { Male } \\
\& 37 \text { female with unilat- } \\
\text { eral lower limb } \\
\text { lymphoedema of various } \\
\text { causes } \\
\text { Mean age (SD) by group: } \\
\text { Grp 1. } 34.8 \text { (13.6) } \\
\text { Grp 2. } 38.6 \text { (15.8) } \\
\text { Mean \% Ex Vol by group } \\
\text { (SD calculated from re- } \\
\text { ported SE) } \\
\text { Grp 1. 22.6\% (21.90) } \\
\text { Grp 2. 20.1\% (19.49) }\end{array}$ & $\begin{array}{l}\text { Group } 1 \\
\text { Coumarin } 2 \text { x } 200 \mathrm{mg} \\
\text { daily } \\
\text { Group } 2 \\
\text { placebo - no details } \\
\text { After } 6 \text { months mi- } \\
\text { crowave heating + ban- } \\
\text { daging given to both } \\
\text { groups daily for } 2 \text { courses } \\
\text { of } 40 \text { days }\end{array}$ & $\begin{array}{l}\text { Outcomes assessed } \\
\text { monthly but only start } \& \\
\text { end reported. } \\
\text { Volume to level of hip } \\
\text { measured by water dis- } \\
\text { placement } \\
\text { Sum of } 6 \text { circumferences } \\
\text { taken every } 10 \mathrm{~cm} \\
\text { Tissue tonometry - ratio } \\
\text { of swollen to normal; in- } \\
\text { crease in values indicates } \\
\text { softening } \\
\text { Symptoms of swelling, } \\
\text { burning pain, feeling of } \\
\text { heaviness, restricted mo- } \\
\text { bility each scored as im- } \\
\text { proved, same, worse }\end{array}$ \\
\hline Zhang 1990 & same trial as above & & & \\
\hline Loprinzi 1999 & $\begin{array}{l}\text { Appears to be Multi-cen- } \\
\text { tre - USA } \\
\text { Method of randomisa- } \\
\text { tion and blinding not } \\
\text { stated } \\
12 \text { month crossover trial: } \\
\text { Trial groups: } \\
\text { Grp 1. coumarin 1st (n ?) } \\
\text { Grp 2. placebo 1st (n ?) } \\
\text { Withdrawals } \\
\text { exclusions: }\end{array}$ & $\begin{array}{l}140 \text { patients aged 33-84; } \\
\text { unknown source; } \\
\text { with breast cancer-re- } \\
\text { lated lymphoedema of } \\
\text { upper limb } \\
\text { All were women; } \\
\text { Stratified for age, cancer } \\
\text { treatment, history of cel- } \\
\text { lulitis, } \\
\text { duration of oedema, time } \\
\text { since surgery / DXT, Ta- } \\
\text { moxifen therapy. } \\
\text { Degree of oedema at start }\end{array}$ & $\begin{array}{l}6 \text { month } \\
\text { coumarin } 2 \times 100 \mathrm{mg} \text { b.d. } \\
/ 2 \text { x lactose tabs b.d then } \\
\text { switched. } \\
\text { Not clear whether or not } \\
\text { women continued with } \\
\text { their usual physical treat- } \\
\text { ment. }\end{array}$ & $\begin{array}{l}\text { Calculated volume from } \\
\text { surface measurements us- } \\
\text { ing formula for volume } \\
\text { of a cylinder. } \\
\text { Volume Data available } \\
\text { for } 120 / 140 \text { at } 6 \text { months; } \\
93 / 140 \text { at } 12 \text { months } \\
\text { Also analysed circumfer- } \\
\text { ences } 5 \text { set points } \\
\text { Phys- }\end{array}$ \\
\hline
\end{tabular}


Table 6. 5,6 Benzo-a-pyrone (coumarin, 5,6BaP) Studies (Continued)

\begin{tabular}{|c|c|c|c|c|}
\hline & $\begin{array}{l}\text { n } 47 / 140 \text { in all } \\
\text { n } 2 / 47 \text { withdrew at start } \\
\text { (? which groups) - } 1 \text { inel- } \\
\text { igible; } 1 \text { withdrew start- } \\
\text { ing trt; } \\
\text { n } 6 / 140 \text { stopped treat- } \\
\text { ment by crossover point; } \\
\text { further } 12 / 140 \text { stopped } \\
\text { treatment by end of trial; } \\
\text { n } 1 / 140 \text { died after } 6 \text { mnth } \\
\text { point; } \\
\text { no } \\
\text { surements available for } n \\
26 / 140 \text { - ? at what point } \\
\text { they did not return } \\
\text { Adverse events: } \\
\text { No diff in either grp ex- } \\
\text { cept for evidence of hep- } \\
\text { atotoxicity: sig. higher } \\
\text { during coumarin - } \\
\text { n } 9 / 139 \text { ( } 6 \% \text { ) v } 0 \text { with } \\
\text { placebo }\end{array}$ & $\begin{array}{l}\text { by groups - } \\
\text { Grp 1. } 32.9 \% \text { (SD ?) } \\
\text { ExV } \\
\text { Grp 2. } 30.6 \% \text { (SD ?) } \\
\text { ExV } \\
\text { Baseline grading of phys- } \\
\text { ical symptoms by group: } \\
\text { Grp 1. } 1.4 \mathrm{n} 67 \\
\text { Grp 2. } 1.4 \mathrm{n} 71\end{array}$ & & $\begin{array}{l}\text { ical symptoms graded } 0- \\
\text { 3: none to severe, } \\
\text { assessed } \\
\text { questionnaire: } \\
\text { Swelling, pressure, tight- } \\
\text { ness, heaviness, loss of } \\
\text { mobility. } \\
\text { Questioned } \\
\text { to which medication was } \\
\text { most helpful }\end{array}$ \\
\hline Casley-Smith 1993(3) & $\begin{array}{l}12 \text { month crossover trial } \\
\text { Randomised by random } \\
\text { number table by pharma- } \\
\text { cist } \\
4 \text { trial groups: } \\
\text { Grp 1. arms coumarin 1st } \\
\text { (n 18) } \\
\text { Grp 2. arms placebo 1st } \\
\text { (n 13) } \\
\text { Grp 3. legs coumarin 1st } \\
\text { (n 10) } \\
\text { Grp } 4 . \text { legs placebo } 1 \text { st (n } \\
11 \text { ) } \\
\text { Withdrawals / exclusions } \\
\text { - } \\
\text { n } 11 \text { / } 63 \text { in all: } \\
\text { n } 5 \text { / } 31 \text { and n } 5 \text { / } 21 \text { ei- } \\
\text { ther moved away or had } \\
\text { difficulty reaching study } \\
\text { centre - doesn't say at } \\
\text { which point they with- } \\
\text { drew; }\end{array}$ & $\begin{array}{l}63 \text { patients source un- } \\
\text { known: } \\
31 \text { with upper limb } \\
\text { oedema all unilateral all } \\
\text { as a result of breast cancer } \\
\text { treatment; } \\
21 \text { unilateral lower limb } \\
\text { of various causes. } \\
\text { All ISL grade } 2 \\
\text { Gender by group: } \\
\text { Grp 1. } \mathrm{m}=0 ; \mathrm{f}=18 \\
\text { Grp 2. } \mathrm{m}=0 ; \mathrm{f}=13 \\
\text { Grp 3. } \mathrm{m}=2 ; \mathrm{f}=8 \\
\text { Grp 4. } \mathrm{m}=3 ; \mathrm{f}=8 \\
\text { Mean age by group (SD } \\
\text { calculated from } \mathrm{SE}) \text { : } \\
\text { Grp 1. } 63 \text { (9.75) } \\
\text { Grp 2. } 62(15.12) \\
\text { Grp 3. } 48(16.10) \\
\text { Grp 4. } 55 \text { (14.89) } \\
\text { Mean duration of } \\
\text { oedema in by group (SD }\end{array}$ & $\begin{array}{l}6 \text { months } 2 \times 200 \mathrm{mgs} \\
\text { coumarin o.d } \\
\text { OR } \\
2 \text { tabs placebo o.d; fol- } \\
\text { lowed by } \\
6 \text { months on the other } \\
\text { treatment. } \\
\text { All other physical treat- } \\
\text { ments stopped I month } \\
\text { before trial. }\end{array}$ & $\begin{array}{l}\text { Main outcome was limb } \\
\text { volume measured by wa- } \\
\text { ter displacement } \\
\text { Assessments made } \\
\text { monthly but only start } \& \\
\text { end reported. } \\
\text { Combined the data so no } \\
\text { baseline for each of the } 4 \\
\text { grps }\end{array}$ \\
\hline
\end{tabular}


Table 6. 5,6 Benzo-a-pyrone (coumarin, 5,6BaP) Studies (Continued)

$\begin{array}{ll}\text { n 1 / 21 excluded as sel- } & \text { calculated from SE): } \\ \text { dom returned for f-up } & \text { Grp 1. 8.3 (6.78) } \\ & \text { Grp 2. 7.5 (6.12) } \\ & \text { Grp 3. 15.6 (18.00) } \\ & \text { Grp 4. 18.2 (13.90) }\end{array}$

The same author, J.R. Casley-Smith, was involved in three of five of the trials. His assistance in preparing another of the reports for publication was acknowledged in the paper (Chang 1996), as was his assistance in reviewing the protocol of the another trial ( Loprinzi 1999). Only two of the reports (Casley-Smith 1993(2); Casley-Smith 1993(3)) described the method of randomisation, both used random number tables. In the latter of these patients were matched prior to randomisation to, amongst other factors, the severity of their oedema, however, it was reported that the Chinese authorities insisted that randomisation be weighted in favour of the treatment group. In practice, this weighting was only apparent in the smallest group, that of the most severe grade, where twice as many patients were randomised to treatment; the other grades were evenly matched in treatment and placebo groups.

One report (Chang 1996) stated that "double-blind procedures" were followed but did not specify what these were. The remaining studies made no mention of the method of blinding. The reports of the Indian trial (Casley-Smith 1993(1); Jamal 1989) raise doubts as to how the trial was blinded. In this trial there were four trial groups and two drugs, $\mathrm{BaP}$ and diethylcarbamazine (DEC), compared in combination and with placebo. The dose of DEC was calculated as $6 \mathrm{mg} / \mathrm{kg}$ per day but no further detail was given. Among the list of reasons for withdrawals, the investigators stated that some "found the BaP tablets too big to swallow" and that some "did not like their reactions to DEC", suggesting that it was possible to distinguish treatments.

All of the trials tested the same dose of coumarin (400mg once a day) against placebo. One of the Chinese trials (Chang 1996) added microwave heating plus bandaging to the treatment regimen for both groups for the second half of the 12 month trial. The Indian trial (Casley-Smith 1993(1); Jamal 1989) and the second Chinese trial (Casley-Smith 1993(2)) were apparently conducted concurrently and tested $\mathrm{BaP}$ against placebo, $\mathrm{BaP}$ against DEC, DEC against placebo, and placebo against placebo. A total of 583 patients appear to have been randomised and of these, 132 were withdrawn or excluded.
In all reports, it was difficult to trace the numbers withdrawn and the numbers included in the analyses; the reasons for withdrawal were seldom given in detail. The report of the American trial ( Loprinzi 1999) and Chinese trial (Casley-Smith 1993(2)) were clearer about withdrawals than any of the others but even here there were discrepancies. In the first of these, a crossover trial, two participants were reported as withdrawing at the start of the trial but it was not clear from which group; the number reported as starting the trial on placebo first $(n=71)$ was reported differently $(n=70)$ in the first figure outlining the results.

The second crossover trial took place in Australia (Casley-Smith 1993(3)) and gave reasons for the exclusions but did not clarify whether they took place before or after the crossover point. The Chinese trial investigating heat plus coumarin (Chang 1996, Zhang 1990) had no withdrawals. The report of the Indian trial (Casley-Smith 1993(1)), which allowed the inclusion of patients with bilateral oedema, introduced confusion by referring to the number of affected limbs ( $\mathrm{n}=183)$ as well as the number of participants ( $n=163$ out of 216). A table giving details of the gender, age, grade and duration of the oedema of the patients in all four trial groups $(n=183)$ is at odds with the number of patients $(n=195)$ who attended for initial assessment. Nowhere were the figures for the number of patients (as opposed to limbs) reported.

\section{Effects of interventions}

Included studies investigating $\mathrm{O}$-(b-hydroxyethyl)-rutoside (oxerutin, HR) studies

All three trials used changes in limb volume as the main outcome of treatment : two trials (Mortimer 1995; Taylor 1993), calculated limb volumes from surface measurements while the third (Piller 1988), used water displacement. One trial measured skin temperature (Piller 1988) and two measured tissue tone with a tonometer (Piller 1988; Taylor 1993). All three trials assessed physical symptoms.

There was insufficient data provided in any of the trials to calculate the per cent reduction, or increase, in baseline excess limb volume. Standard deviations or confidence intervals and the numbers in 
the groups at the different stages of the trial were missing for all the data in two of the reports (Mortimer 1995; Piller 1988) and for much of the data in the third, making any attempt at meta-analysis impossible. The authors of one of the English trials (Mortimer 1995) concluded that there had been some slight benefit from the active drug on limb volume, in effect the oedema had been stabilised while the use of placebo resulted in a small increase; but no effect on symptoms. These findings were echoed in the second English trial (Taylor 1993). The investigators concluded that while on HR, volume and tissue tone had been reduced by clinically unimportant amounts, with no effect on symptoms. They did not recommend its use in established lymphoedema. The authors of the Australian trial (Piller 1988) reported that the active drug "showed significant to very significant improvements" compared to placebo, in volume, skin temperature, tissue tone and symptoms.

Included studies investigating Ruscus aculeatus and hesperidin methyl chalcone (Cyclo 3 Fort) studies

The main outcome in this single trial of C3F (Cluzan 1990) was limb volume as calculated from surface measurements using the formula for a truncated cone. Physical symptoms were assessed using visual analogue scores: mobility, feelings of softness and heaviness. "Arm quality" was assessed by both patients and investigators and reported as "improved", "no change" or "deteriorated".

No baseline data on the per cent excess limb volume was provided and the results were reported as reduction or increase of the per cent excess volume (presumably mean results). Mild and moderate lymphoedema were also reported separately; as were arm and forearm measurements. The numbers in the groups at each followup point were not given nor the standard deviations or confidence intervals. The active groups were reported as expressing a total decrease in the whole limb of $1 \%$ at one month; $9 \%$ at two months; and $13 \%$ at three months. In the placebo groups, the total decrease was $0.5 \%$ at one month; an increase of $1 \%$ at two months; and an increase of $3 \%$ at three months. The VAS scores for symptoms were not reported and no baseline data reported. Data were expressed as a per cent increase or decrease in the symptoms. By the end of the trial, softness, heaviness and mobility were all increased in the C3F group (up by $112 \%, 33 \%, 34 \%$ respectively) while softness and mobility were reduced in the placebo group (by $5 \%$ and $2 \%$ respectively) and heaviness increased (5\%). It is difficult, logically, to explain the large apparent increase in heaviness in the C3F group. In the assessment of arm quality, it seems that the figure quoted was the per cent of patients and investigators reporting that category. In the $\mathrm{C} 3 \mathrm{~F}$ group, $70 \%$ of patients reported improvement as against $32 \%$ in the placebo group. Presumably the figure for investigators relates to the per cent of patients showing improvement: $75 \%$ in the C3F group and $20 \%$ in the placebo group.

The authors concluded that $\mathrm{C} 3 \mathrm{~F}$ caused a significant reduction in arm oedema, compared to placebo, and that the reduction was more marked in the forearm than the upper arm. They suggested this is due to a greater ratio of fat to fluid in this part of the limb. Included studies investigating diosmin plus hesperidin (Daflon 500mg) study

In the only study of Daflon (Pecking 1997), the main outcomes were lymphoscintigraphic parameters (lymphatic migration speed as an indirect measure of lymphatic pumping, clearance and halflife measured as the diffusion of the technetium-labelled colloid) assessed at the start and end of the trial; limb volume was calculated from circumference measurements using the formula for a truncated cone. Visual analogue scales were used to assess discomfort; heaviness was scored on a four point scale from "absent", "inconstant "(presumably meaning intermittent), "constant" , "invalid" (probably a mistranslation of "incapacitating”). Assessments were carried out every two months.

Ninety-four patients completed the study, 46 on active drug and 48 on placebo. The authors concluded that there were no significant differences between the active and placebo groups in any of the lymphoscintigraphic parameters or for volume over time; no actual data were provided. Both groups were reported as showing significant reductions in discomfort and, unlike the findings in the C3F study (Piller 1988), the active group showed a significant improvement in heaviness. A greater proportion of patients with constant heaviness fell into the intermittent category and the figures for the incapacitating category did not change at all . Data on the results of lymphoscintigraphy and volume were provided for a "subset" of 24 patients considered to have more severe oedema ( 10 on Daflon, 14 on placebo); severe oedema was defined as an arm circumference measurement of greater than $2 \mathrm{~cm}$ over the normal arm. In the C3F study (Cluzan 1990) reviewed above a circumference of greater than $2 \mathrm{~cm}$ and less than $5 \mathrm{~cm}$ over the normal arm was considered an indicator of mild oedema so it is difficult to see how the above criteria defined severe oedema. In this subset, Daflon significantly improved migration speed and halflife; clearance was not significantly different between the groups but showed a greater tendency to improve in the Daflon group. Changes in discomfort, heaviness and volume were not significantly different between the two groups. The excess volume had increased by $13 \%$ in the placebo group $(n=14)$ and decreased by $6 \%$ in the Daflon group $(n=10)$. No values for SDs were given

Included studies investigating coumarin plus troxerutin (Lysedem, coumarin plus TER, CTR) studies

Two of the three studies (Burgos 1999; Desprez 1985) used limb volume as the main outcome measure, the third uses limb circumferences at three set points on the limb. In addition, lymphoscintigraphic parameters (speed, clearance and half-life) was used in one of the studies (Desprez 1985), and a "morphological survey" was conducted using isotope lymphography in another (Cluzan 1996). All three included subjective assessments of symptoms; one (Cluzan 1996) also reported on episodes of infection, and one ( Burgos 1999) asked patients and investigators to assess efficacy. There were problems with the reporting of the results of trials 
in all three papers. None reported the numbers in the groups at each assessment nor supplied standard deviations or confidence intervals. Baseline data was usually missing, making interpreting any changes difficult.

Included studies investigating 5,6 benzo-a-pyrone (coumarin, $5,6 \mathrm{BaP})$

The main outcome measure in all identified trials was change in the size of the affected limb. The American trial (Loprinzi 1999) calculated limb volume from circumference measurements using the formula for volume of a cylinder. The Australian (Casley-Smith 1993(3)) and one of the Chinese trials (Chang 1996) used water displacement to measure the whole of the limb volume.

A problem arose with the measurements used in the second Chinese trial (Casley-Smith 1993(2)), which reported using the truncated cone method to calculate volume from circumferences. However it was clear that only half the lower limb was measured as the volumes reported were too small for them to represent the whole limb. The authors did not make this point explicit but did state that oedema predominantly affected the lower leg and foot. This was in contrast to the Indian study where the whole leg was affected. Even if this difference were so, omitting to measure the whole limb leaves open the possibility that while part of the limb reduced, another part did not, a tendency revealed in the French trial of C3F (Cluzan 1990).

In the Indian trial, the authors make clear in the second report ( Casley-Smith 1993(1)) that water displacement was used to measure limb volumes only up to $30 \mathrm{~cm}$ from the heel (i.e. to the level of the knee); this was despite the statement that the whole leg tended to be affected. In addition, they included the patients with bilateral oedema (estimated at 20) in the data analyses by using the mean of the normal limbs in the trial as controls rather than each patient being their own control.

For those trials not reporting change as the percentage reduction or increase in the excess volume over the normal limb, it was possible to calculate this figure from the data provided in only one trial (Loprinzi 1999). The authors' conclusions were based on an analysis that ignored the crossover design (as did the authors of the Australian crossover trial (Casley-Smith 1993(3)). Data were available, however, on normal and swollen limb volumes, which allowed results to be calculated for the original trial groups. This was important in the case of crossover trials with withdrawals after the crossover point, since any data after this point could be considered biased. Standard deviations were reported or could be calculated for only two of the trials (Casley-Smith 1993(3); Chang 1996).

The three trials involving the same author, (Casley-Smith 1993(1); Casley-Smith 1993(2); Casley-Smith 1993(3); Jamal 1989) and the Chinese trial looking at heat plus BaP (Chang 1996; Zhang 1990), all concluded that BaP was significantly more effective at reducing oedema than placebo and more effective at improving physical symptoms. In the case of the Indian study (Casley-Smith 1993(1); Jamal 1989) and one of the Chinese trials (Casley-Smith
1993(2)), these reductions were apparently very large. The American trial (Loprinzi 1999) concluded that there was no difference observed between $\mathrm{BaP}$ and placebo in any of the outcomes under investigation. There was insufficient data across the included trials to draw any conclusions on secondary outcomes such as quality of life, pain and tonometry.

\section{I S C U S S I O N}

For many patients with chronic oedema, particularly those living in tropical countries or in places where services are inaccessible, the idea of a drug to treat their condition is very appealing. The history of using benzo-pyrones to treat lymphoedema dates back many years and was perhaps an inevitable progression from their use in venous disease. The main focus of these drugs is to limit fluid filtration rather than stimulate drainage; there are also claims for their ability to lyse proliferative tissue. Unfortunately, the trials described here do little to strengthen the argument for using these substances to treat lymphoedema. This is an oedema that results not for the most part from increased filtration of fluid but from a reduced capacity to drain fluid. Although some studies recruited adequate numbers of patients, it was difficult to be confident of the quality of these trials because of the lack of information provided. For the most part it proved difficult to keep a tally of the patients recruited, randomised and withdrawn, making the findings difficult to interpret. The quality of the reporting of these trials was certainly too low to allow any attempt at meta-analysis.

This review has highlighted the need for consensus on the use of objective outcomes to assess the effects of treatment on chronic oedema. Limb volume (of the whole limb rather than just the affected part so as to pick up any tendency simply to shift fluid from one part to another) is really the only way to monitor excess volume; circumferences, even if taken at frequent intervals, provide limited information. There is a need, where possible, to use the normal contra-lateral limb as a control since factors such as weight gain or loss and environmental factors, such as ambient temperature, can affect the size of the limbs. Oedema extending onto the body is a relatively common occurrence in lymphoedema and is difficult to assess. A sensitive objective method of doing so is needed. Lymphoscintigraphy is gaining recognition as an excellent tool in the diagnosis of lymphoedema and the differential diagnosis of the various types of lymphoedema. It has not yet been proven to be effective and consistent in measuring lymph flow and is, therefore, of limited value in assessing changes as a result of treatment.

There is a growing recognition that researchers must look beyond the immediate and most obvious problem of size when studying lymphoedema and take into account other outcomes such as the quality of the affected soft tissues. This presents a challenge to 
provide non-invasive assessment. When it comes to assessing outcomes such as pain or discomfort and other quality of life issues, there is scope for modifying existing tools and validating that they measure problems specific to lymphoedema.

\section{AUTHORS, CONCLUSIONS}

\section{Implications for practice}

It is not possible to draw conclusions about the effectiveness of Benzopyrones on lymphoedema from these trials. On an individual basis, patients may report an improvement in symptoms such as heaviness, tightness or aching when taking these preparations but any improvement should be weighed against the lack of information about the long-term effects of these drugs. It is difficult to see how their routine use could be supported by the current evidence.

\section{Implications for research}

As with so many aspects of the management of lymphoedema, good quality, properly randomised, multi-centre (preferably international) trials are required to answer questions surrounding the use of benzo-pyrones in the management of this condition.

\section{ACKNOWLEDGEMENTS}

Our thanks go to the the members of the editorial office of the Cochrane Breast Cancer Group for assisting in all stages of the review and especially to Sharon Parker and Joanne Telenta.

Thanks are also expressed to the study investigators who provided additional information and were generally helpful.

\section{REF E R E N C E S}

\section{References to studies included in this review}

\section{Burgos 1999 \{published data only\}}

* Burgos A, Alcaide A, Alcoba C, Azcona JM, Garrido J, Lorente C, et al.Comparative study of the clinical efficacy of two different coumarin dosages in the management of arm lymphedema after treatment for breast cancer. Lymphology 1999;32(1):3-10.

Casley-Smith 1993(1) \{published data only\}

* Casley-Smith JR, Jamal S, Casley-Smith J. Reduction of filaritic lymphoedema and elephantiasis by 5,6 benzo-alpha- pyrone (coumarin), and the effects of diethylcarbamazine (DEC). Annals of tropical medicine and parasitology 1993;87(3):247-58. [MEDLINE: 94079467]

Casley-Smith 1993(2) \{published data only\} * Casley-Smith JR, Wang CT, Zi-hai C. Treatment of filarial lymphoedema and elephantiasis with 5,6-benzo- alpha-pyrone (coumarin). British Medical Journal 1993;307(6911):1037-41. [MEDLINE: 94072886]

Casley-Smith 1993(3) \{published data only\} * Casley-Smith JR, Morgan RG, Piller NB. Treatment of lymphedema of the arms and legs with 5,6-benzo-[alpha] pyrone. New England Journal of Medicine 1993;329(16):1158-63. [MEDLINE: 93390563]

Chang 1996 \{published data only\}

* Chang TS, Gan JL, Fu KD, Huang WY. The use of 5,6 benzo[alpha]-pyrone (coumarin) and heating by microwaves in the treatment of chronic lymphedema of the legs. Lymphology 1996;29 (3):106-11. [MEDLINE: 97052720]

Cluzan 1990 \{published data only\}

* Cluzan R, Pecking A. Benzopyrone (lysedem) double blind 
crossing over study in patients with secondary upper limb edemas. Progress in lymphology XII: proceedings of the XIIth International Congress of Lymphology ICS887 1990;29:453-4.

Cluzan 1996 \{published data only\}

* Cluzan RV, Alliot F, Ghabboun S, Pascot M. Treatment of secondary lymphedema of the upper limb with CYCLO 3 FORT. Lymphology 1996;29(1):29-35. [MEDLINE: 96282826]

\section{Desprez 1985 \{published data only\}}

* Desprez-Curely JP, Cluzan R, Pecking A. Benzo-pyrones and post-mastectomy lymphedemas, double-blind trial placebo versus sustained release coumarin with trioxyethylrutin (TER). Progress in Lymphology X. 1985:203-5.

\section{Jamal 1989 \{published data only\}}

* Jamal S, Casley Smith JR. The effects of 5,6 benzo-[a]-pyrone (coumarin) and DEC on filaritic lymphoedema and elephantiasis in India. Preliminary results. Annals of tropical medicine and parasitology 1989;83(3):287-90.

Loprinzi 1999 \{published data only\}

* Loprinzi CL, Kugler JW, Sloan JA, Rooke TW, Quella SK, Novotny P, et al.Lack of effect of coumarin in women with lymphedema after treatment for breast cancer. New England Journal of Medicne 1999;340(5):346-50. [MEDLINE: 99119166]

\section{Mortimer 1995 \{published data only\}}

* Mortimer PS, Badger C, Clarke I, Pallett J. A double-blind, randomized, parallel-group, placebo-controlled trial of O-( beta hydroxyethyl)-rutosides in chronic arm oedema resulting from breast cancer treatment. Phlebology 1995;10(2):51-5.

\section{Pecking 1997 \{published data only\}}

* Pecking AP, Fevrier B, Wargon C, Pillion G. Efficacy of Daflon $500 \mathrm{mg}$ in the treatment of lymphedema (secondary to conventional therapy of breast cancer). Angiology 1997;48(1):93-8. [MEDLINE: 97150814]

Piller 1988 \{published data only\}

* Piller NB, Morgan RG, Casley Smith JR. A double-blind, crossover-trial of O-( beta -hydroxyethyl)-rutosides (benzo-pyrones) in the treatment of lymphoedema of the arms and legs. British journal of plastic surgery 1988;41(1):20-7.

Taylor 1993 \{published data only\}

* Taylor HM, Rose KE, Twycross RG. A double-blind clinical trial of hydroxyethylrutosides in obstructive arm lymphoedema.

Phlebology 1993;8(Suppl. 1):22-8.

Zhang 1990 \{published data only\}

* Zhang D. Benzo-pyrones in the treatment of chronic

lymphoedema of the arms and legs. Zhonghua Yi Xue Za Zhi 1990; 70(11):655-6.

\section{References to studies excluded from this review}

\section{Clodius 1978 \{published data only\}}

* Clodius L, Piller N.B. Conservative therapy for postmastectomy lymphedema. Chirurgia maxillofacialis \& plastica 1978;4:193-202.

\section{Additional references}

\section{Badger 2000}

Badger CMA, Peacock JL, Mortimer PS. A randomized controlled, parallel-group trial comparing multilayer bandaging followed by hosiery versus hosiery alone in the treatment of patients with lymphedema of the limb. Cancer 2000;88(12):2832-7.

Bates 1994

Bates DO, Levick JR, Mortimer PS. Quantification of rate and depth of pitting in human edema using an electronic tonometer. Lymphology 1994;27:159-72.

\section{Casley-Smith 1990}

Casley Smith JR, Jamal S, Piller NB, Morgan RG, Wang CT. The effects of all high-protein oedemas and the reduction of all of them by the benzo-pyrones, with particular emphasis on lymphoedema and elephantiasis. Progress in Lymphology XII. Elsevier Science Publishers B.V., 1990:17-22.

\section{Casley-Smith 1991}

Casley-Smith JR, Casley-Smith JR. The benzo-pyrones in the treatment of lymphoedemas and elephantiasis in temperate and tropical countries. Proceedings of the XIII International Congress of Lymphology. Paris: Elsevier Science Publishers B.V., 1990: 471-6.

Casley-Smith 1992

Casley-Smith JR, Casley-Smith JR. Modern treatment of lymphoedema. II. The benzopyrones. Australasian Journal of Dermatology 1992;33(2):69-74.

\section{Casley-Smith 1993(4)}

Casley Smith J. Treatment of lymphoedema and other high-protein oedemas with benzo-pyrones. Journal of the Irish College of Physicians and Surgeons 1993;22(Suppl. 1):67-8.

Casley-Smith 1993(5)

Casley-Smith JR, Casley-Smith JR. Benzo-pyrones reduce filaritic lymphoedema \& elephantiasis; DEC has little effect. Lymphology 1993:353-6.

\section{Casley-Smith 1993(6)}

Casley-Smith JR, Casley-Smith JR. Volume alterations in lymphoedema; untreated and after complex physical therapy (C.P.T.), benzo-pyrones or both. Proceedings of the XIV International Congress of Lymphology: Progress in Lymphology XIV. Washington: Arizona Press, 1993.

\section{Casley-Smith 1999}

Casley-Smith JR. Benzo-pyrones in the treatment of lymphoedema. International angiology : a journal of the International Union of Angiology 1999;18(1):31-41.

\section{Cesarone 1992}

Cesarone MR, Laurora G, Ricca A, BelcaroG, Pomante P, et al.Acute effect of hydroxyethylrutosides on capillary filtration in normal volunteers, patients with hypertension and in patients with diabetic microangiopathy. A dose comparison study. VASA. Zeitschrift fur Gefasskrankheiten 1992;21:76-80.

\section{Erickson 2001}

Erickson VS, Pearson ML, Ganz PA, Adams J, Kahn KL. Arm Edema in Breast Cancer Patients. Journal of the National Cancer Institute 2003;93(2):96-111. 


\section{Foldi 1985}

Foldi E, Foldi M, Weissleder H. Conservative treatment of lymphoedema of the limbs. Angiology 1992;March:171-80.

\section{Hoult 1996}

Hoult JR, Paya M. Pharmacological and biochemical actions of simple coumarins: natural products with therapeutic potential. General Pharmacology 1996;27(4):713-22.

\section{Levick 1991}

Levick JR. An Introduction to Cardiovascular Physiology. First Edition. London: Butterworth, 1991.

\section{Mirolo 1995}

Mirolo BR, Bunce IH, Chapman M, et al.Psychosocial benefits of postmastectomy lymphoedema therapy. Cancer Nursing 1995;18: $197-205$.

\section{Moffatt 2003}

Moffatt CJ, Franks PJ, Doherty DC, Williams AF, Badger C, Jeffs E, et al.Lymphoedema: an underestimated health problem. Quarterly Journal of Medicine 2003;96(10):731-8.

\section{Mortimer 1995}

Mortimer PS. Managing Lymphoedema. Clinical and Experimental Dermatology 1995;20:98-106.

\section{Olszewski 2000}

Olszewski W. Clinical efficacy of micronized purified flavonoid fraction (MPFF) in edema. Angiology 2000;51(1):25-9.

\section{Petrek 1998}

Petrek JA, Heelan MC. Incidence of breast carcinoma-related lymphedema. Cancer 1998;83(12):Suppl:2776-81.

\section{Piller 1976(1)}

Piller NB. Conservative treatment of acute and chronic lymphoedema with benzo-pyrones. Lymphology 1976;9(4):132-7.

\section{Ramalet 2000}

Ramelet AA. Pharmacologic aspects of a phlebotropic drug in CVIassociated edema. Angiology 2000;51(1):19-23.

\section{Roztocil 1993}

Roztocil K, Prerovsky I, Olivia I. The effects of hydroxyethylrutosides on capillary filtration rate in the lower limbs of man. European journal of clinical pharmacology 1993;11:435-8.

Sitzia 1997

Sitzia J, Stanton AWB, Badger C. A review of outcome indicators in the treatment of chronic limb oedema. Clinical Rehabilitation 1997;11:181-91.

\section{Tobin 1993}

Tobin M, Lacey HJ, Meyer L, Mortimer PS. The psychological morbidity of breast cancer related arm swelling. Cancer 1993;72 (11):3248-52

\section{Wadworth 1992}

Wadworth AN, Faulds D. Hydroxyethylrutosides: A review of its pharmacology, and therapeutic efficacy in venous insufficiency and related disorders. Drugs 1996;44(6):1013-32.

* Indicates the major publication for the study 
CHARACTERISTICS OF STUDIES

\section{Characteristics of included studies [ordered by study ID]}

Burgos 1999

\begin{tabular}{|c|c|}
\hline Methods & $\begin{array}{l}\text { 12 month trial in Spain } \\
\text { Trial groups } \\
\text { 1. Lysedem (n 38) } \\
\text { 2. Lysedem (n 39) } \\
\text { Method of randomisation and blinding not reported } \\
\text { Withdrawals / exclusions: } 24 \text { in all: } \\
\text { 1. } 15 / 38 \\
\text { 6/15 voluntary } \\
6 / 15 \text { adverse events } \\
\text { 3/15 lost to f-up } \\
\text { 1/15 protocol violation } \\
(=16 / 38 \text { not } 15) \\
\text { 2. } 9 / 39 \\
1 / 9 \text { voluntary } \\
\text { 5/9 adverse events } \\
\text { 1/9 lost to f-up } \\
\text { 1/9 "other causes" } \\
(=8 / 39 \text { not } 9) \\
\text { States } 53 \text { completed study } \\
\text { "3 more minor protocol violations" occurred: } \\
\text { 1. } 1 \\
2.2 \\
\text { Adverse events as above }\end{array}$ \\
\hline Participants & $\begin{array}{l}77 \text { patients from } 6 \text { centres: } 1 \text { breast unit, } \\
2 \text { rehabilitation depts, } \\
2 \text { depts vascular surgery, } \\
1 \text { oncology dept; } \\
\text { all female; } \\
\text { all with unilateral upper limb; } \\
\text { all breast ca-related lymphoedema; } \\
\text { all ISL Grade } 2 \\
\text { Degree of oedema at start by group } \\
\text { 1. } 25.9 \% \\
\text { 2. } 22.6 \% \\
\text { Duration of oedema not stated but all less than } 10 \text { years } \\
\text { Age by groups - mean (SD) } \\
1.52 .0 \text { yrs }(8 . .0) \\
\text { 2. } 52.8 \text { yrs }(7.0)\end{array}$ \\
\hline Interventions & $\begin{array}{l}\text { Group } 1 . \\
\text { coumarin + troxerutin (Lysedem) } 90 \mathrm{mg} \text { daily } \\
\text { versus } \\
\text { Group } 2 \\
\text { coumarin + troxerutin (Lysedem) } 135 \mathrm{mg} \text { daily }\end{array}$ \\
\hline
\end{tabular}




\section{Burgos 1999 (Continued)}

Outcomes Volumes of normal \& affected limbs measured electronically. Expressed as changes in excess volume (ExV)

6 Clinical symptoms assessed by investigator on 5 point scale: hardness, heaviness, neurological signs, sensation of oedema at wrist, forearm, upper arm.

Patient \& investigator assessed efficacy of treatment as none, mild, moderate, good, excellent - reported as \% of patients. No baseline data

Notes

Casley-Smith 1993(1)

\begin{tabular}{|c|c|}
\hline Methods & $\begin{array}{l}2 \text { year trial conducted in India } \\
\text { Subjects matched for grade, duration, age \& sex in quadruplets then randomised. } \\
\text { Method of randomisation and blinding not stated } \\
4 \text { trial groups: } \\
\text { 1. placebo + placebo n ? } \\
\text { 2. placebo + } 5,6 \mathrm{BaP} n \text { ? } \\
\text { 3. DEC + placebo n ? } \\
\text { 4. DEC + 5,6 BaP n? } \\
\text { Withdrawals / exclusions } \\
21 \text { / } 216 \text { did not appear for initial assessment; } \\
32 \text { / } 216 \\
\text { excluded because attended for less than } 2 \mathrm{f} \text {-up assessments; } \\
5 \text { / ? "found BaP tabs too big to swallow; } \\
20 \text { /? "did not like their reactions to DEC" } \\
\text { Presume the } 25 \text { above are part of the } 32 \text { excluded rather than in addition to them. } \\
\text { States only } 163 \text { patients reported on (giving } 183 \text { limbs as some were bilateral) }\end{array}$ \\
\hline Participants & $\begin{array}{l}216 \text { patients bilateral \& unilateral lymphoedema of the lower limbs secondary to filariasis } \\
195 \text { attended for initial assessment } \\
\text { Mean age by group: } \\
\text { 1. } 50.5 \text { yrs } \\
\text { 2. } 53.2 \text { yrs } \\
\text { 3. } 50.7 \text { yrs } \\
\text { 4. } 47.2 \text { yrs } \\
\text { Gender by group: } \\
\text { 1. } m=9 ; \mathrm{f}=30 \text { total }=39 \\
\text { 2. } \mathrm{m}=20 ; \mathrm{f}=32 \text { total }=52 \\
\text { 3. } \mathrm{m}=12 ; \mathrm{f}=32 \text { total }=44 \\
\text { 4. } \mathrm{m}=20 ; \mathrm{f}=28 \text { total= } 48 \\
\text { Total }=183 \\
\text { [At odds with stated fig of } 163 \text { patients reported on; does say there were } 183 \text { limbs as some pts were had bilat swelling] } \\
\% \text { excess volume at start by grade } \& \text { group: mean (no SD) } \\
\text { Group } 1: \\
\text { grade } 2=19 \% \text {; } \\
\text { grade } 3=55 \% \text {; } \\
\text { grade } 4-5=78 \% \\
\text { Group } 2 \text { : } \\
\text { grade } 2=21 \% \text {; }\end{array}$ \\
\hline
\end{tabular}




\section{Casley-Smith 1993(1) (Continued)}

\begin{tabular}{|c|c|}
\hline & $\begin{array}{l}\text { grade } 3=63 \% \\
\text { grade } 4-5=78 \% \\
\text { Group } 3: \\
\text { grade } 2=25 \% \\
\text { grade } 3=60 \% \\
\text { grade } 4-5=80 \% \\
\text { Group } 4: \\
\text { grade } 2=19 \% \\
\text { grade } 3=60 \% \\
\text { grade } 4-5=79 \%\end{array}$ \\
\hline Interventions & $\begin{array}{l}\text { Groups } \\
\text { 1. Placebo }+ \text { placebo } \\
\text { 2. Placebo }+\mathrm{BaP} \\
\text { 3. DEC + placebo } \\
\text { 4. DEC }+\mathrm{BaP} \\
\mathrm{BaP} 2 \times 200 \mathrm{mg} \text { tabs o.d } \\
\mathrm{DEC} 6 \mathrm{mg} / \mathrm{kg} / \text { day [so was dose calculated individually for each subject? If so did no. of tabs vary? If so how was it } \\
\text { blinded?] } \\
\text { Placebo - no details given } \\
\text { No other treatments given }\end{array}$ \\
\hline Outcomes & $\begin{array}{l}\text { Main outcome was leg volume assessed } 3 \text { monthly. Used water displacement to measure up to } 30 \mathrm{~cm} \text { above the heel } \\
\text { ie only to level of knee. Looked at } \% \text { Ex V over normal limb. At least } 20 \text { patients had bilateral oedema so used means } \\
\text { of normal limbs as control for bilateral limbs. } \\
\text { Also made circ measurements but did not report on these } \\
\text { Patients questioned about symptoms: } \\
\text { Feelings of swelling \& bursting, Also re secondary infections } \\
\text { Clinical exam of ulcers }\end{array}$ \\
\hline
\end{tabular}




\begin{tabular}{|c|c|}
\hline Methods & $\begin{array}{l}2 \text { year trial conducted in China } \\
\text { Randomised using random number tables. } \\
\text { Method of blinding not stated. } \\
2 \text { trial groups: } \\
\text { 1. coumarin n } 64 \\
\text { 2. placebo n } 40 \\
\text { Subjects stratified for grade of oedema, duration, sex and age. } \\
\text { Chinese authorities apparently insisted that more people be assigned to treatment than placebo. (but this was only } \\
\text { the case for Grade } 3 \text { oedema - grades } 1 \& 2 \text { were similar size groups) } \\
\text { Withdrawals / exclusions } \\
21 / 104 \text { in all } \\
8 \text { / } 21 \text { withdrew from active group in } 1 \text { st year: } 6 / 8 \text { "reasons unconnected to drug"; } 2 \text { felt they were cured } \& \text { refused } \\
\text { further treatment ( } 1 \text { at } 1 \text { month, } 1 \text { after } 5 \text { months). } \\
13 / 21 \text { withdrew during } 2 \text { nd year: } 11 / 13 \text { from active group } 2 / 13 \text { from placebo group. "all for reasons unconnected } \\
\text { to trial" } \\
\text { Adverse effects "were mild" } 60 \% \text { coumarin pts felt dizzy/sleepy, } 3 \text { slight nausea } \& \text { diarrhoea, } 2 \text { skin rash. All symptoms } \\
\text { disappeared after } 1 \text { st month. } 5 \text { patients withdrew with infective hepatitis (?? When ?? if included in withdrawals } \\
\text { above) }\end{array}$ \\
\hline Participants & $\begin{array}{l}104 \text { patients with unilateral lower limb lymphoedema, from around the Province. } \\
\text { Gender by group: } \\
\text { 1. } \mathrm{m}=31 ; \mathrm{f}=25 \\
\text { 2. } \mathrm{m}=25 ; \mathrm{f}=15 \\
\text { Mean age: } \\
\text { 1. } 55 \text { years } \\
\text { 2. } 58 \text { years } \\
\text { Duration of oedema: } \\
129 \text { years } \\
\text { 2. } 33 \text { years }\end{array}$ \\
\hline
\end{tabular}

Interventions Group 1

Coumarin (5,6 BaP) 2 x 200mg o.d

Versus

Group 2

Placebo (? Details)

No other treatments given

Outcomes Main outcome limb volume. States this calculated from surface measurements using truncated cone method [but elsewhere same authors say that they only looked at differences in circumferences; authors also imply that whole leg was measured (they talk about summing 4 truncated cones) but the reported volumes are too small for whole leg must be below knee only.]

Assessed condition of skin, hair growth,ulcers, freq of infection. Categorised each clinical feature as none, slight, mild, moderate, severe 


\begin{tabular}{|c|c|}
\hline Methods & $\begin{array}{l}12 \text { month crossover trial } \\
\text { Randomised by random number table by pharmacist } \\
4 \text { trial groups: } \\
\text { 1. arms coumarin } 1 \text { st }(\mathrm{n} 18) \\
\text { 2. arms placebo } 1 \text { st }(\mathrm{n}=13) \\
\text { 3. legs coumarin } 1 \text { st }(\mathrm{n}=10) \\
\text { 4. legs placebo } 1 \text { st }(\mathrm{n}=11) \\
\text { Withdrawals / exclusions: } \\
11 / 63 \text { in all } \\
5 / 31 \text { and } 5 / 21 \text { either moved away or had difficulty reaching study centre - doesn't say at which point they withdrew } \\
1 / 21 \text { excluded as seldom returned for follow up }\end{array}$ \\
\hline Participants & $\begin{array}{l}63 \text { patients source unknown: } \\
31 \text { with upper limb oedema all unilateral all as a result of breast cancer treatment } \\
21 \text { unilateral lower limb of various causes. } \\
\text { All ISL grade } 2 \\
\text { Gender by group: } \\
\text { 1. } \mathrm{m}=0 ; \mathrm{f}=18 \\
\text { 2. } \mathrm{m}=0 ; \mathrm{f}=13 \\
\text { 3. } \mathrm{m}=2 ; \mathrm{f}=8 \\
\text { 4. } \mathrm{m}=3 ; \mathrm{f}=8 \\
\text { Mean age by group (SD calculated from } \mathrm{SE}) \text { : } \\
\text { 1. } 63(9.75) \\
\text { 2. } 62(15.12) \\
\text { 3. } 48(16.10) \\
\text { 4. } 55(14.89) \\
\text { Mean duration of oedema in by group (SD calculated from SE): } \\
\text { 1. } 8.3(6.78) \\
\text { 2. } 7.5(6.12) \\
\text { 3. } 15.6(18.00) \\
\text { 4. } 18.2(13.90)\end{array}$ \\
\hline Interventions & $\begin{array}{l}6 \text { months } 2 \times 200 \text { mgs coumarin o.d } \\
\text { OR } \\
2 \text { tabs placebo o.d; } \\
\text { followed by } \\
6 \text { months the other trt. } \\
\text { All other physical trts stopped } 1 \text { month before trial. }\end{array}$ \\
\hline Outcomes & $\begin{array}{l}\text { Main outcome was limb volume measured by water displacement } \\
\text { Assessments made monthly but only start } \& \text { end reported } \\
\text { Combined the data so no baseline for each of the } 4 \text { grps }\end{array}$ \\
\hline Notes & \\
\hline
\end{tabular}




\section{Chang 1996}

\begin{tabular}{|c|c|}
\hline Methods & $\begin{array}{l}12 \text { month parallel group trial in China; } \\
\text { Method of randomisation and blinding not stated } \\
2 \text { trial groups: } \\
\text { 1. coumarin ( } 30) \\
\text { 2. placebo ( } 30 \text { ) } \\
\text { Stratified for grade of oedema, age, sex, duration of oedema, cause of oedema. } \\
\text { Withdrawals - none reported }\end{array}$ \\
\hline Participants & $\begin{array}{l}60 \text { patients, source unknown (China) . } 23 \text { Male } \& 37 \text { female with unilateral lower limb lymphoedema of various } \\
\text { causes } \\
\text { Mean age (SD) by group: } \\
\text { 1. } 34.8(13.6) \\
\text { 2. } 38.6(15.8) \\
\text { Mean \% Ex Vol by group (SD calculated from reported SE) } \\
\text { 1. } 22.6 \%(21.90) \\
\text { 2. } 20.1 \%(19.49)\end{array}$ \\
\hline Interventions & $\begin{array}{l}\text { Group } 1 \\
\text { Coumarin } 2 \times 200 \mathrm{mg} \text { daily } \\
\text { Group } 2 \\
\text { placebo - no details } \\
\text { After } 6 \text { months microwave heating + bandaging given to both groups daily for } 2 \text { courses of } 40 \text { days }\end{array}$ \\
\hline Outcomes & $\begin{array}{l}\text { Outcomes assessed monthly but only start \& end reported. } \\
\text { Volume to level of hip measured by water displacement } \\
\text { Sum of } 6 \text { circumferences taken every } 10 \mathrm{~cm} \\
\text { Tissue tonometry - ratio of swollen to normal; increase in values indicates softening } \\
\text { Symptoms of swelling, burning pain, feeling of heaviness, restricted mobility each scored as improved, same, worse }\end{array}$ \\
\hline & \\
\hline
\end{tabular}




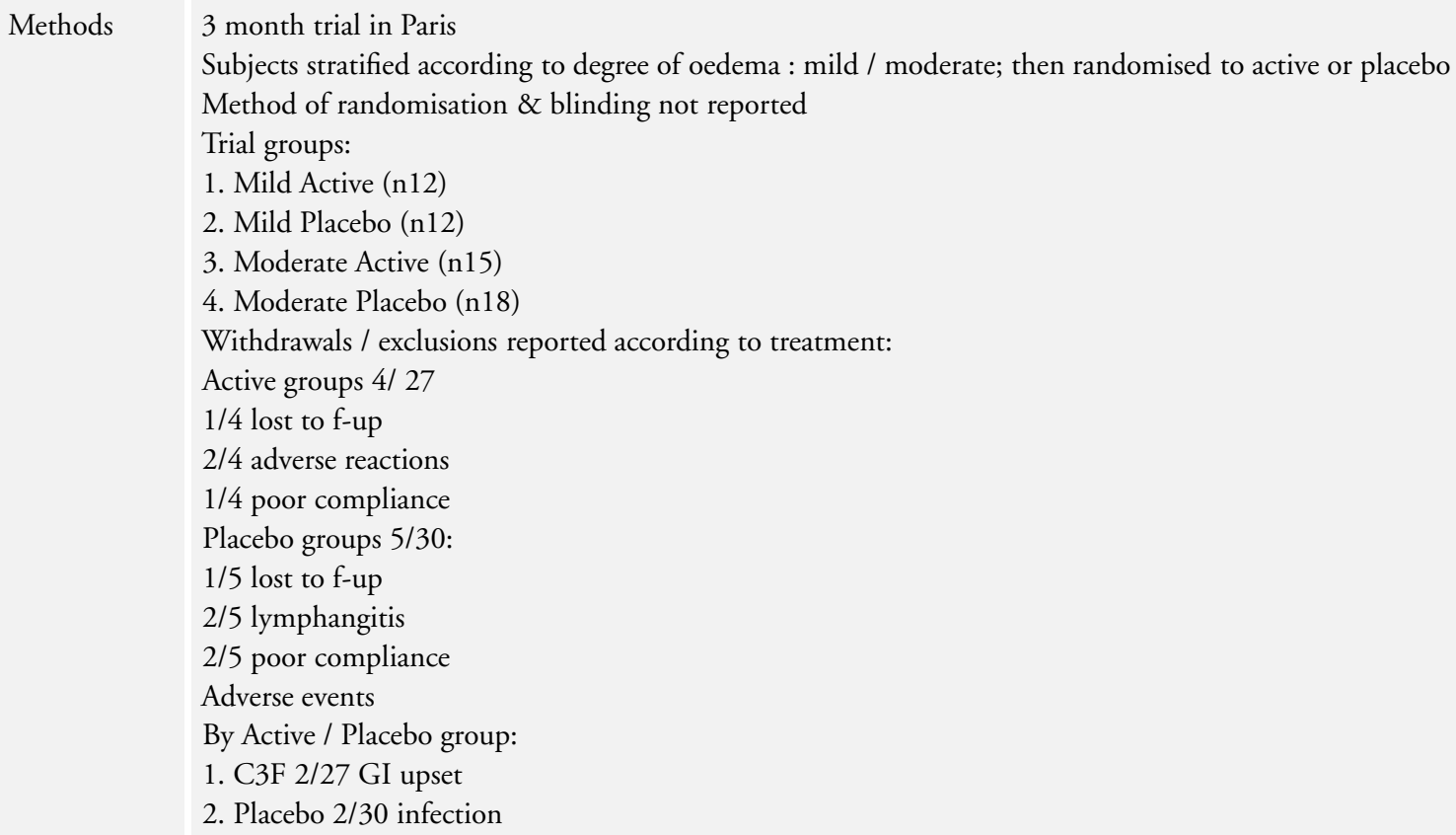

Participants 57 patients from Lymphology Unit;

all female;

all with upper limb;

all breast ca-related oedema.

Degree of oedema at start not stated

Duration of oedema not stated

Age not stated except that $>18$ yrs

No details of cancer treatment stated

Interventions Cyclo 3 Fort (C3F) 3 caps tds

Versus

Placebo 3 caps tds

plus MLD $2 \mathrm{x}$ week for those who were already receiving it. No details on the $\mathrm{n}$ in each group receiving MLD

Outcomes Calculated limb volume from surface measurements using formula for truncated cones. Reported as \% change in excess volume (ExV)

No baseline data reported 


\section{Cluzan 1996}

$\begin{array}{ll}\text { Methods } & 9 \text { month trial in France } \\ \text { Method of randomisation \& blinding not reported. } & \text { Trial groups: } \\ \text { 1. Lysedem (n?) } \\ \text { 2. Placebo (n?) } \\ \text { Withdrawals/exclusions: } 2 \text { in all, no reasons given } \\ \text { 1. } 1 / \text { ? } \\ \text { 2. } 1 / \text { ? } \\ \text { Yet states } 79 \text { completed trial; } \\ \text { Only } 55 \text { pts had lymphscintigraphy data analysed: } \\ \text { 1. } 27 / \text { ? } \\ \text { 2. } 28 / \text { ? } \\ \text { Adverse events } 3 / \text { ? } \\ \text { By group: } \\ \text { 1. } 2 / 2 \text { GI upset } \\ \text { 2. } 1 / 1 \text { GI upset }\end{array}$

$\begin{array}{ll}\text { Participants } & 80 \text { patients; } \\ & \text { source unknown; } \\ \text { all with secondary upper limb lymphoedema; } & \text { no details on cause of swelling or on gender. } \\ & \text { Degree of oedema at start not stated } \\ & \text { Duration of oedema not stated } \\ \text { Age not stated }\end{array}$

Interventions Group 1:

9 months Lysedem 6 tabs daily,

Group 2:

9 months Placebo 6 tabs daily.

Outcomes Volume difference between normal \& affected limbs calculated from circumferences

No baseline data provided

3 point clinical score assessing hardness, heaviness, pain, subjective improvement - ? reported as mean combined scores

Lymphscintigraphy parameters:

$1 / 2$ life

Clearance

Speed 


\begin{tabular}{|c|c|}
\hline Methods & $\begin{array}{l}18 \text { month trial in France } \\
\text { Method of randomisation } \& \text { blinding not stated } \\
2 \text { trial groups: } \\
\text { 1. coumarin for } 18 \text { months } n=45 \\
\text { 2. placebo for } 6 \text { months then coumarin for remaining } 12 \text { months } n=46 \\
\text { Withdrawals / exclusions } \\
1 / 92 \text { - ? at what stage which group, or why } \\
\text { Adverse effects } \\
\text { Included dizziness, nausea, pollakiuria, pruritus } \& \text { menstrual flow. Details not given of these by group. } \\
\text { At } 6 \text { mths by group: } \\
\text { 1. } 6 \\
\text { 2. } 2 \\
\text { At } 12 \text { mths by group: } \\
\text { 1. } 4 \\
2.0 \\
\text { At } 18 \text { mths none. }\end{array}$ \\
\hline Participants & $\begin{array}{l}92 \text { patients all with post-mastectomy lymphoedema } \\
\text { of the upper limb. Presume all female but not stated. } \\
\text { No difference between them re age, affected limb, former treatment, duration of oedema, circumstances of appearance, } \\
\text { infection, subjective symptoms, "areas of blocking" according to isotope lymphography }\end{array}$ \\
\hline Interventions & $\begin{array}{l}\text { Group } 1 \\
\text { 1. Coumarin + trioxyethylrutin } 9 \text { tabs for first } 6 \text { mths; then } 6 \text { tabs up to } 18 \text { mths" } \\
\text { Group } 2 \\
\text { 2. Placebo for first } 6 \text { mths then } 6 \text { tabs coumarin TER up to } 18 \mathrm{mnths}\end{array}$ \\
\hline
\end{tabular}

Outcomes Assessed circumference measurements at 3 sites: wrist, forearm, arm

No baseline data given

Reported \% change in circ at each site

Also assessed subjective symptoms

Episodes of lymphangitis

"Morphological survey" with isotope lymphography

Notes

Jamal 1989

Methods 2 year trial conducted in India

Subjects put into groups matched for grade age sex

Method of randomisation and blinding not stated

4 trial groups:

1. placebo + placebo $n=41$

2. placebo $+5,6 \mathrm{BaP} n=7$

3. $\mathrm{DEC}+$ placebo $\mathrm{n}=9$

4. $\mathrm{DEC}+5,6 \mathrm{BaP}$ n42 


\section{Jamal 1989 (Continued)}

\begin{tabular}{ll} 
Participants & $\begin{array}{l}169 \text { reported on - ? whether this was no. randomised. } \\
\text { Only } 20 \text { had completed the trial } \\
\text { [Mean f-up reported here is } 9.3 \text { months }] \\
\text { Pts chosen with "apparently normal" contra-lateral leg }\end{array}$ \\
\hline Interventions & $\begin{array}{l}\text { Groups } \\
\text { 1. Placebo + placebo } \\
\text { 2. Placebo }+\mathrm{BaP} \\
\text { 3. DEC }+ \text { placebo } \\
\text { 4. DEC }+\mathrm{BaP} \\
\text { BaP } 2 \times 200 \mathrm{mg} \text { tabs o.d } \\
\text { DEC } 6 \mathrm{mg} / \mathrm{kg} / \text { day } \\
\text { [so was dose calculated individually for each subject? } \\
\text { If so did no. of tabs vary? } \\
\text { If so how was it blinded?] } \\
\text { Placebo - no details given }\end{array}$ \\
\hline Outcomes & $\begin{array}{l}\text { Main outcome was leg volume assessed } 3 \text { mnthly. } \\
\text { Used water displacement to measure. Looked at } \% \text { Ex V over normal limb.. }\end{array}$ \\
\hline Notes & \begin{tabular}{l} 
\\
\hline
\end{tabular}
\end{tabular}

\section{Loprinzi 1999}

\begin{tabular}{|c|c|}
\hline Methods & $\begin{array}{l}\text { Appears to be Multi-centre - USA } \\
\text { Method of randomisation and blinding not stated } \\
12 \text { month crossover trial: } \\
\text { Trial groups: } \\
\text { 1. coumarin } 1 \text { st ( } \mathrm{n} \text { ?) } \\
\text { 2. placebo } 1 \text { st ( } \mathrm{n} \text { ?) } \\
\text { Withdrawals / exclusions: } \\
47 / 140 \text { in all } \\
2 / 47 \text { withdrew at start (? which grps) - } 1 \text { ineligible; I withdrew starting trt } \\
6 / 140 \text { stopped treatment by crossover point; } \\
\text { further } 12 / 40 \text { stopped treatment by end of trial } \\
1 / 140 \text { died after } 6 \text { mnth point; } \\
\text { no vol measurements available for } 26 / 140 \text { - ? at what point they did not return } \\
\text { Adverse events: } \\
\text { No diff in either grp except for evidence of hepatotoxicity : sig. higher during coumarin - n } 9 / 139(6 \%) \mathrm{v} 0 \text { with } \\
\text { placebo }\end{array}$ \\
\hline Participants & $\begin{array}{l}140 \text { patients aged 33-84; unknown source; } \\
\text { with breast cancer-related l'oedema of upper limb } \\
\text { All were women; } \\
\text { Stratified for age, cancer treatment, history of cellulitis, duration of oedema, time since surgery / DXT, Tamoxifen } \\
\text { therapy. } \\
\text { Degree of oedema at start by groups - } \\
1.32 .9 \% \text { (SD ?) ExV }\end{array}$ \\
\hline
\end{tabular}




\title{
Loprinzi 1999 (Continued)
}

\author{
2. $30.6 \%$ (SD ?) $\mathrm{ExV}$ \\ Baseline grading of physical symptoms by group: \\ 1. $1.4 \mathrm{n}=67$ \\ 2. $1.4 \mathrm{n}=71$
}

Interventions 6 month coumarin $2 \times 100 \mathrm{mg}$ b.d. $/ 2$ x lactose tabs b.d then switched.

Not clear whether or not women continued with their usual physical treatment.

Outcomes Calculated volume from surface measurements using formula for volume of a cylinder.

Volume Data available for 120 /140 at 6 months; 93 / 140 at 12 months

Also analysed circumferences 5 set points

Physical symptoms graded 0-3: none to severe, assessed by questionnaire:

Swelling, pressure, tightness, heaviness, loss of mobility

Questioned as to which medication was most helpful

Notes

Mortimer 1995

\begin{tabular}{l} 
Methods \\
Trial groups \\
1. HR (n 25) \\
2. Placebo (n 21) \\
Method of randomisation not reported but confirmed by authors as central phone randomisation used. Blinding \\
based on a pharmacy scheme using identical containers $\&$ tabs. \\
Withdrawals 27 in all: \\
Group $1: 15 / 25$ \\
10/15 missed visits \\
2/15 relapsed cancer \\
1/15 skin reaction \\
1/15 persistent upset stomach \\
1/15 exacerbation of migraine \\
Group $2: 12 / 21$ \\
8/12 missed visits \\
1/12 protocol violation \\
1/12 CVA \\
1/12 pain $\&$ soreness of finger nails \\
1/12 too little oedema \\
\hline
\end{tabular}

Participants 46 patients randomised from Lymphoedema Clinic

All female, upper limb only, all breast ca-related

No details on age, duration of oedema or cancer treatment

Degree of oedema at start by group - mean (no SD):

1. $42 \%$ Excess Volume

2. 38\% Excess Volume

Interventions 6 months HR $3 g$ daily versus

6 months placebo daily.

All patients continued with standard compression treatment, skin care and exercises. 
Mortimer 1995 (Continued)

Outcomes Calculated swollen / normal limb volumes from surface measurements using frustrum of a cone formula 6 symptoms assessed on 5 point scale and on Visual Analogue Scales

Pain assessed on McGill pain questionnaire

Notes

\section{Pecking 1997}

\begin{tabular}{|c|c|}
\hline Methods & $\begin{array}{l}6 \text { month trial in France } \\
\text { Method of randomisation } \& \text { blinding not reported } \\
\text { Two treatment groups: } \\
\text { 1. Diosmin }(\mathrm{n}=51) \\
\text { 2. Placebo ( } \mathrm{n}=53) \\
\text { Withdrawals/exclusions: } 10 \text { in all, no reasons given: } \\
\text { 1. } 5 / 51 \\
\text { 2. } 5 / 53 \\
\text { So } 94 \text { completed trial } \\
\text { Adverse events by group } \\
\text { 1. } 8 / 51 \text { : } \\
3 / 8 \text { GI upset } \\
5 / 8 \text { miscellaneous } \\
\text { 2. } 6 / 53 \text { : } \\
\text { 4/6 GI upset } \\
\text { 2/6 miscellaneous }\end{array}$ \\
\hline Participants & $\begin{array}{l}\text { 104 patients } \\
\text { source unknown } \\
\text { all female } \\
\text { all with upper limb } \\
\text { all with breast ca-related oedema. } \\
\text { Degree of oedema at start not stated } \\
\text { Onset after cancer treatment by group - mean months (SD) } \\
\text { 1. } 33.8 \text { ( } 48) \\
\text { 2. } 35.1 \text { (39.4) } \\
\text { Duration of oedema in months at start by group, mean (SD): } \\
\text { 1. } 46.8 \text { (59.9) } \\
\text { 2. } 31.1 \text { (39.4) } \\
\text { Mean (SD) age by group: } \\
\text { 1. } 61.5 \text { yrs (10.8) } \\
\text { 2. } 57.3 \text { yrs }(9.8) \\
\text { Body weight at start by group - mean (SD): } \\
\text { 1. } 62.3 \mathrm{~kg}(8.1) \\
\text { 2. } 63.3 \mathrm{~kg}(8.6) \\
\text { Surgery (\% of pts) by group: } \\
\text { 1. } 98 \% \\
\text { 2. } 100 \% \\
\text { Radiotherapy (\% of ots) by group: } \\
1.82 .4 \%\end{array}$ \\
\hline
\end{tabular}


Pecking 1997 (Continued)

\begin{tabular}{|c|c|}
\hline & $\begin{array}{l}\text { 2. } 90.6 \% \\
\text { Chemotherapy ( } \% \text { of pts) by group: } \\
\text { 1. } 33.3 \% \\
\text { 2. } 60.4 \%\end{array}$ \\
\hline Interventions & $\begin{array}{l}\text { Daflon } 500 \text { mg x } 2 \text { tabs daily } \\
\text { versus } \\
\text { placebo x } 2 \text { tabs daily } \\
\text { No other treatment given }\end{array}$ \\
\hline Outcomes & $\begin{array}{l}\text { Calculated excess limb volume from surface measurements using truncated cone formula. } \\
\text { Assessed every } 2 \text { months but no data provided for pts other than for a subset of } 24 \text { with "more severe oedema" } \\
\text { Used lymphscintigraphy to measure migration speed of tracer, clearance and half-life. } \\
\text { No data provided for the } 94 \text { only for subset of } 24 \\
\text { Assessed discomfort by VAS. } \\
\text { Heaviness assessed on } 4 \text { point scale. }\end{array}$ \\
\hline Notes & \\
\hline
\end{tabular}

\section{Piller 1988}

Methods

12 month crossover trial:

Trial groups - $\mathrm{n}$ after withdrawals:

1. Upper limb HR 1st (n13)

2. Upper limb placebo 1st (n13)

3. Lower limb HR 1st (n7)

4. Lower limb placebo 1st (n7)

Upper and lower limbs randomised according to separate lists. No details on blinding.

Withdrawals / exclusions: 10 in all

10/10 hospital too far away;

Not stated whether withdrawals occurred before or after crossover nor which group they came from .

So 40 patients completed trial

Adverse events: $1 / 40$

1 in placebo grp had nausea $\&$ giddiness; not stated whether upper or lower limb

Participants 50 patients randomised source unknown.

All ISL Grade II oedema:

26/50 with postmastectomy l'oedema of upper limb

$14 / 50$ with l'oedema of lower limb, due to various causes

Gender by groups:

1. $\mathrm{m}=0 ; \mathrm{f}=13$

2. $m=0 ; f=13$

3. $\mathrm{m}=5 ; \mathrm{f}=2$

4. $m=1 ; f=6$

Age by groups- mean (SD)

1.56 yrs (8.6)

2. 59 yrs $(10)$

3. 51 yrs $(15)$

4. 49 yrs (22) 
Piller 1988 (Continued)

Degree of oedema at start by groups - mean \% excess volume over the normal limb; estimated from graphs:
1. $40 \%$
2. $38 \%$
3. $27 \%$
4. $13 \%$
Duration of oedema by groups - mean (SD)
1. $4.0 \mathrm{yrs}(5.8)$
2. $9.2 \mathrm{yrs}(7.0)$
3. $16.0 \mathrm{yrs}(18.0)$
4. 11.0 yrs $(12.0)$

Interventions 6 month HR $3 \mathrm{~g}$ daily, $\mathrm{v}$

6 month placebo - no details given

All other treatments such as compression hose stopped 1 month before trial.

Outcomes Measured limb volume by water displacement; (also circumferences)

Physical symptoms \& feeling of well-being scored on 5 point scale from much worse to improved

Tissue tone measured by Tonometry at 2 sites on each limb (proximal \& distal)- the higher the figure the softer the tissues.

Skin temperature measured by digital skin thermometer - 1 electrode placed on swollen limb \& 1 on normal limb; reported as \% difference between them

Patients asked their preference for treatment

Notes

Taylor 1993

\begin{tabular}{|c|c|}
\hline Methods & $\begin{array}{l}12 \text { month crossover trial } \\
\text { Trial groups: } \\
\text { 1. HR first (n 16) } \\
\text { 2. Placebo first (n } 15) \\
\text { Method of randomisation and blinding not reported } \\
\text { Withdrawals } 9 \text { in all: } \\
\text { Group } 1=5 / 16 \\
1 / 5 \text { possible adverse reaction } \\
1 / 5 \text { stress of trial } \\
1 / 5 \text { progression of cancer } \\
2 / 5 \text { family stress } \\
\text { Group } 2=4 / 15 \\
1 / 4 \text { possible adverse reaction } \\
1 / 4 \text { family stress } \\
1 / 4 \text { viral hepatitis } \\
1 / 4 \text { progression of cancer } \\
\text { Not stated whether withdrawals occurred before or after crossover } \\
\text { Adverse events see above }\end{array}$ \\
\hline Participants & $\begin{array}{l}44 \text { approached for randomisation, } 31 \text { were randomised; } \\
\text { all patients from Lymphoedema Clinic; } \\
\text { unilateral upper limb only; }\end{array}$ \\
\hline
\end{tabular}


Taylor 1993 (Continued)

\begin{tabular}{|c|c|}
\hline & $\begin{array}{l}\text { all but } 1 \text { breast ca-related. } \\
1 \text { male } 30 \text { female } \\
\text { Degree of oedema at start by groups - mean \% ExV (no SD reported): } \\
\text { 1. } 35 \% \\
\text { 2. } 30 \% \\
\text { Duration of oedema by groups - mean (SD calculated from SE): } \\
\text { 1. } 7.9 \text { yrs }(6.0) \\
\text { 2. } 7.9 \text { yrs }(5.4) \\
\text { Age by groups - mean (SD calculated from SE) } \\
\text { 1. } 56.4 \text { yrs }(18.7) \\
\text { 2. } 60.3 \text { yrs }(10.0)\end{array}$ \\
\hline Interventions & $\begin{array}{l}6 \text { month HR } 3 \text { g daily, } \\
6 \text { month placebo. } \\
\text { All patients continued their usual physical treatment regime of compression sleeves exercise, massage \& skin care. }\end{array}$ \\
\hline Outcomes & $\begin{array}{l}\text { Calculated swollen \& normal limb volumes from surface measurements using cylinder formula. } \\
\text { Measured tissue tone by Tonometry. Expressed as \% difference in mm moved by weight of tonometer between swollen } \\
\& \text { normal limbs } \\
\text { Assessed joint mobility by scoring functional movements } \\
\text { Assessed pain using McGill Pain Quest. and VAS scores }\end{array}$ \\
\hline Notes & \\
\hline
\end{tabular}

\section{Zhang 1990}

\begin{tabular}{l|l} 
Methods & same trial as above \\
\hline Participants & \\
\hline Interventions & \\
\hline Outcomes & Notes \\
\hline
\end{tabular}


Characteristics of excluded studies [ordered by study ID]

Clodius 1978 States that 92 out of 133 patients were "randomised" to treatment while 41 patients received nothing - but it is not clear that they were really randomised. The treated patients were seen in one department of the hospital while the untreated patients were seen in other departments and knew nothing of the trial 
DATA AND ANALYSES

This review has no analyses.

\section{WHAT'S NEW}

Last assessed as up-to-date: 25 September 2003.

22 October 2008 Amended Converted to new review format.

\section{H I S T O R Y}

Protocol first published: Issue 3, 2001

Review first published: Issue 2, 2004

16 August 2003 New citation required and conclusions have changed Substantive amendment

\section{CONTRIBUTIONSOFAUTHORS}

$\mathrm{CB}$ was the principal reviewer and wrote up the review. $\mathrm{CB}$ and NP were responsible for the extraction of the data. NP acted as the second reviewer and collated the final draft of the review. PM provided clinical direction and both KS and PM advised, and helped write both the protocol and the review.

\section{DECLARATIONS OF INTEREST}

None known.

\section{SOURCES OF SUPPORT}

\section{Internal sources}

- Royal College of Nursing, UK. 


\section{External sources}

- No sources of support supplied

\section{NDEX TERMS}

\section{Medical Subject Headings (MeSH)}

Anticoagulants [therapeutic use]; Benzopyrans [*therapeutic use]; Coumarins [therapeutic use]; Diosmin [therapeutic use]; Extremities; Hydroxyethylrutoside [analogs \& derivatives; therapeutic use]; Lymphedema [* drug therapy]; Plant Extracts [therapeutic use]; Randomized Controlled Trials as Topic

\section{MeSH check words}

Humans 